FACULDADE DE ECONOMIA, AdMINISTRAÇÃO, CoNTABILIDADE E CIÊNCIA DA INFORMAÇÃO E DOCUMENTAÇÃO PROGRAMA DE PÓS-GRADUAÇÃO EM ADMINISTRAÇÃO

\author{
JÚLIO CÉSAR VERSIANI TEIXEIRA \\ MARIA DA GLÓRIA FERNANDES REIS
}

\title{
CONTRATOS, CONVÊNIOS E PARCERIAS DA FUB: COMPETÊNCIAS NECESSÁRIAS PARA A FORMULAÇÃO E APROVAÇÃO DE PROCESSOS.
}

BRASÍLIA - DF 2006 


\section{JÚLIO CÉSAR VERSIANI TEIXEIRA \\ MARIA DA GLÓRIA FERNANDES REIS}

\section{CONTRATOS, CONVÊNIOS E PARCERIAS DA FUB: COMPETÊNCIAS NECESSÁRIAS PARA A FORMULAÇÃO E APROVAÇÃO DE PROCESSOS.}

Monografia apresentada à Faculdade de Economia, Administração, Contabilidade e Ciência da Informação e Documentação (FACE), da Universidade de Brasília, como requisito parcial para a obtenção do grau de Especialista em Desenvolvimento Gerencial.

Orientador: Prof. Dr. Gileno Fernandes Marcelino

BRASÍLIA - DF 2006 
“Líderes se desenvolvem, não são fabricados." Charles Handy

"Nada melhor do que um sonho para criar o futuro." Victor Hugo

"Se eu não fizer algo, nada irá ficar melhor". Nathaniel Branden. 


\section{AGRADECIMENTOS}

Ao Prof. Dr. César Augusto Tibúrcio Silva que participou da nossa vida acadêmica mostrando o seu companheirismo e paciência.

Ao nosso orientador Prof. Dr. Gileno Fernandes Marcelino que nos fez acreditar que podemos crescer com o nosso esforço e dedicação.

A Prof ${ }^{-}$Miramar Vargas que durante as suas aulas nos orientou a percorrer os caminhos acerca do Comportamento Organizacional, com sabedoria.

A Prof ${ }^{a}$ Maria de Fátima Bruno-Faria que muito colaborou para realização desse trabalho.

Aos colegas da FUB entrevistados, que nos ajudaram nessa conquista.

A todos os professores, pelo auxílio e convívio intelectual durante o curso.

Aos colegas de sala, inestimáveis parceiros e grandes amigos, com quem muito aprendemos.

Aos familiares, que sempre nos apoiaram.

A todos aqueles que colaboraram para o sucesso desse trabalho. 


\section{RESUMO}

REIS, Maria da Glória Fernandes; TEIXEIRA, Júlio César Versiani. Contratos, Convênios e Parcerias da FUB: competências necessárias para a formulação e aprovação de processos. Brasília, DF. Monografia em Curso de Especialização em Desenvolvimento Gerencial - FACE, 2006.

No ambiente da Universidade de Brasília, no qual se procurou focar o presente estudo, buscou-se, por meio de entrevistas, pesquisas de campo e levantamento de dados, diagnosticar os problemas mais graves decorrentes da formulação incorreta de processos para realização de parcerias por intermédio de convênios, contratos e acordos. Como a falta de informações a respeito das normas internas e/ou leis externas, ou a falta de um esquema ou um guia que permita ao gerente ou ao colaborador visualizar, de forma simples, como desenvolver, passo a passo, os trâmites processuais, resultam em prejuízos para a instituição, propõe-se, criar um roteiro que possibilite diminuir tais incorreções visando aperfeiçoar as tramitações e demais processos internos e, por conseguinte valorizar o(s) colaborador(es) envolvido(s), tornado-o(s) mais eficiente(s) e eficaz(es).

Palavras-chave: Convênios, contratos, parcerias, acompanhamento, mudança de paradigmas. 


\section{SUMÁRIO}

1. INTRODUÇÃO

1.1 - FORMULAÇÃO DO PROBLEMA DE PESQUISA

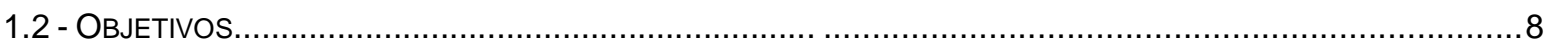

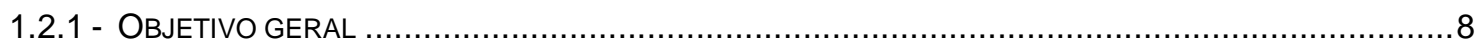

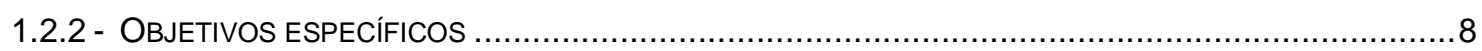

1.3 - JUSTIFICATIVA

2. CONTEXTO ATUAL ....................................................................................... 10

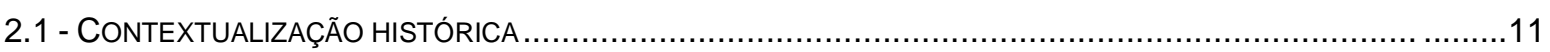

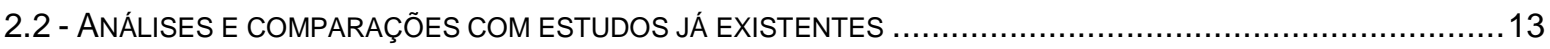

3. METODOLOGIA

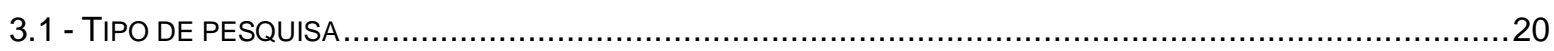

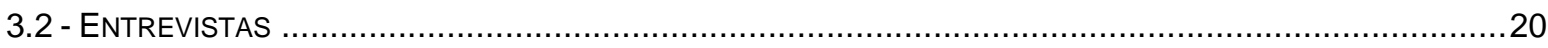

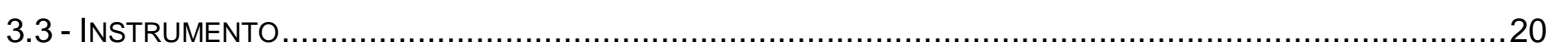

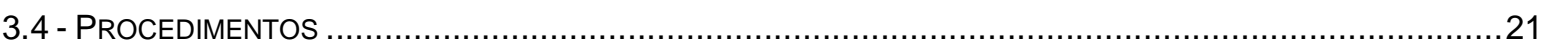

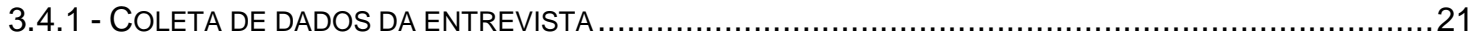

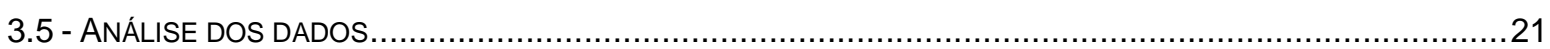

4. APRESENTAÇÃO E DISCUSSÃO DOS RESULTADOS .................................. 22

4.1 - ENTREVISTA COM OS GERENTES DA FUB E COMENTÁRIOS DOS PESQUISADORES...........................22

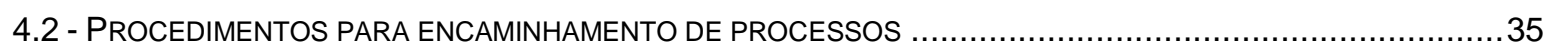

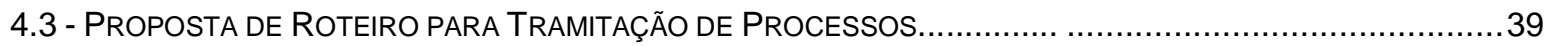

4.4 -TRAMITAÇÃO DE PROCESSOS RELATIVOS A CONTRATOS DE RECEITA .....................................39

4.4.1 - ITENS ELEMENTARES QUE DEVEM INTEGRAR UM PROJETO BÁSICO .................................40

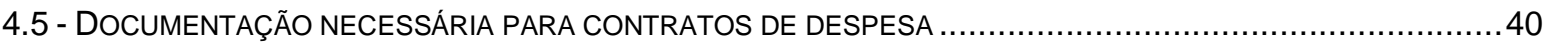

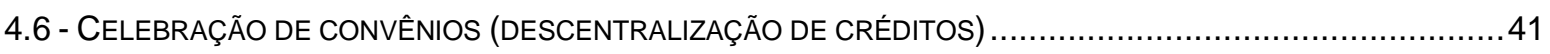

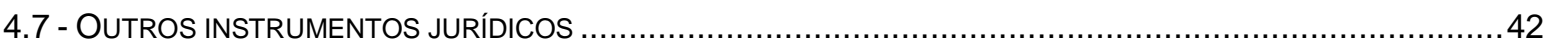

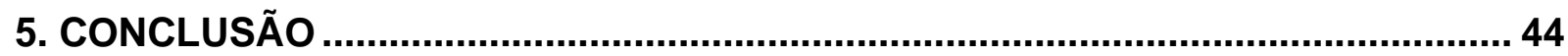

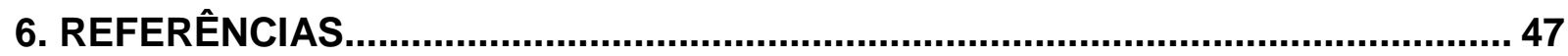

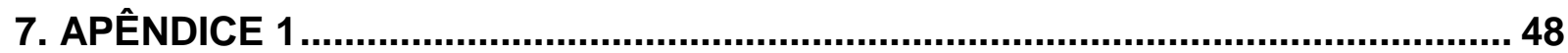

8. APÊNDICE 2

9. APÊNDICE 3

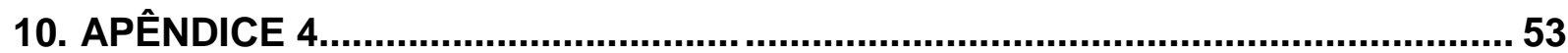

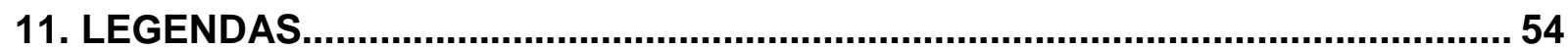

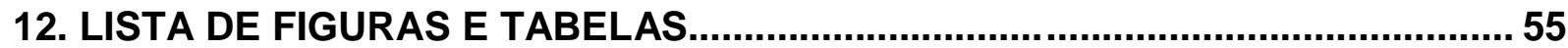




\section{1 - Introdução}

Muitas competências são necessárias para a formulação de processos de contratos, convênios e demais parcerias da Fundação Universidade de Brasília (FUB) com outras organizações públicas e privadas, desde a sua concepção no seio da unidade acadêmica e/ou administrativa até a sua finalização na mesa do Magnífico Reitor, quando o mesmo deverá assinar o referido instrumento e dar início às atividades ali propostas. Diversas dificuldades são encontradas pelos gerentes envolvidos no processo de formalização destes instrumentos, devido tanto às normas específicas que estão sempre sendo modificadas ou aperfeiçoadas, como a dificuldade para o correto procedimento em relação às mesmas.

Os avanços surgidos com a era da informática contribuíram para o aumento da necessidade de adaptação das pessoas às novas formas de trabalho na Universidade de Brasília (UnB). Estes avanços nem sempre são bem-vindos em decorrência do receio de alguns em ter que aceitar mudanças de paradigmas. A FUB foi adaptando-se e criando formas mais ágeis de ação em detrimento daquelas antigas que demandavam maior tempo de finalização dos mais variados processos, tanto na área acadêmica como na administrativa. Diversos cursos foram oferecidos para se aprender novas técnicas de manuseio de equipamentos, devido à substituição das antigas máquinas de escrever por computadores pessoais e equipamentos de xerox-impressoras no lugar das pesadas máquinas de reprodução de apostilas e textos diversos.

Este fator gerou também uma demanda para o aprendizado de programas específicos (softwares) ligados a área de informática tais como: Word, Powerpoint, Dreamweaver, Excel. Bem como o desenvolvimento por parte do Centro de Processamento de Dados de programas que visassem agilizar o trâmite dos processos pela Universidade, a exemplo do sistema UnBDoc. Mesmo diante desses avanços, há necessidade de constantes ajustes na área técnica e de recursos humanos. 


\section{1 - Formulação do problema de pesquisa}

Quais competências são necessárias para que os gerentes contribuam para o alcance de resultados positivos na formulação de processos de contratos, convênios e demais parcerias da FUB com outros órgãos públicos e privados, desde a sua concepção até o seu término?

\section{2- Objetivos}

\subsection{1 - Objetivo Geral}

O objetivo geral desta monografia é, portanto, o de identificar as competências necessárias para que os gerentes e/ou colaboradores alcancem os resultados nos processos de contratos, convênios e demais parcerias da FUB com outros órgãos públicos e privados.

\subsection{2 - Objetivos Específicos}

Como objetivos específicos, pretende-se nesta monografia:

$\checkmark$ Analisar os instrumentos jurídicos já existentes na FUB que objetivam parcerias envolvendo ou não recursos financeiros, no intuito de visualizar o nível de conhecimento e adequar às suas necessidades e exigências;

$\checkmark$ Entrevistar gerentes e colaboradores das unidades acadêmicas e administrativas que mais utilizam esses serviços, no intuito de identificar como melhorar a satisfação desses gerentes e colaboradores na FUB;

$\checkmark$ Sugerir um roteiro que sirva de consulta à comunidade universitária, buscando minimizar a perda de tempo e procedimentos equivocados no encaminhamento de processos. 


\section{3 - Justificativa}

Existe no âmbito da FUB pouco entendimento em relação às normas quanto aos trâmites de documentos entre a maioria dos gerentes de unidades acadêmicas e administrativas e a Administração Central, bem como da correta formalização dos processos que resultam em parcerias que envolvam a FUB. Falando-se em correta formalização, entenda-se o atendimento a contento das normas constantes nas diversas resoluções e atos expedidos pelos Órgãos Colegiados, Conselhos, ViceReitoria e Reitoria da UnB, os quais regulam e direcionam as formas de ação dentro da Fundação Universidade de Brasília, ou seja, definem qual é o melhor caminho a ser trilhado pela FUB para fomentar o seu desenvolvimento.

Além disso, será enfatizado que não somente estas normas devem ser atendidas, mas também se deve atentar as leis que regulam toda a ação relativa à Administração Pública.

A FUB, por ser uma fundação pública se submete às mesmas. São leis que sofrem a fiscalização constante dos órgãos competentes, que por sua vez não fazem diferenciação no trato da coisa pública.

Muitas destas leis e normas limitam, em parte, as parcerias de interesse da FUB que porventura possam ser realizadas. Há, portanto, muito desentendimento entre a unidade interessada no instrumento e a Administração Central que cuida da análise destes instrumentos, seguindo os ditames das leis.

As parcerias são elementos essenciais para captação de recursos, principalmente nos momentos de crise financeira que as universidades públicas passam.

O presente estudo resultou num documento em forma de roteiro, que visa facilitar o entendimento, por parte da comunidade universitária, da importância da correta tramitação de processos relativos às diversas formas de parcerias existentes, desde a sua concepção até a sua finalização, ressaltando os benefícios que as mesmas podem trazer para o crescimento científico e tecnológico da universidade. A orientação existente no site do Serviço de Convênios e Contratos da FUB é boa, porém 
muito extensa e, de certa forma prolixa, fator este que desestimula sua consulta por parte da comunidade em geral.

Assim, este estudo tem o intuito de tentar colaborar para melhorar ainda mais, não só a agilidade no andamento dos processos, mas principalmente o entendimento de qual seria o melhor caminho a se tomar, para o correto encaminhamento dos instrumentos relativos às crescentes parcerias desenvolvidas pela FUB e as diversas organizações tanto públicas quanto privadas.

A proposta de adoção do instrumento de consulta em pauta, fruto do resultado do presente estudo, baseado principalmente nas experiências vividas durante anos de trabalho na FUB, bem como em entrevistas com gerentes e colaboradores lotados nas unidades acadêmicas e administrativas da Universidade, pretende contribuir para a eficiência e eficácia do trabalho desenvolvido por considerável parcela da comunidade universitária.

\section{2 - Contexto Atual}

A forma como a Fundação Universidade de Brasília (FUB) vem conduzindo seus processos administrativos, mais especificamente a formalização, a condução e a aprovação dos mesmos, apesar dos esforços de alguns setores em tornar este processo o mais ágil possível, tem nos levado a detectar, na lida do dia-a-dia, falhas que colaboram para aumentar a morosidade nos seus andamentos.

Assim vislumbra-se, por meio do presente estudo e, em detrimento da pouca bibliografia existente sobre o assunto, de colaborar de forma mais eficaz e eficiente com este importante processo para a trajetória da instituição.

Os autores do presente estudo fazem, primeiramente, um breve histórico da trajetória seguida pela instituição, para em seguida comparar a forma de atuação administrativa da UnB com o pensamento e a experiência da bibliografia nesta área.

Por meio de algumas entrevistas, mostrar-se-á o nível de satisfação da comunidade universitária em relação às formalizações dos processos internos e tramitação de instrumentos jurídicos, e finalmente, apresentar-se-á como sugestão, um roteiro de procedimentos administrativos para a condução de processos, desde a sua idealização até sua a finalização. 


\subsection{Contextualização Histórica}

A Fundação Universidade de Brasília, fundação pública, que foi criada por meio da Lei n. 3.998, pelo então Presidente da República João Belchior Marques Goulart, em 15 de dezembro de 1961, mantém a Universidade de Brasília (UnB), que por sua vez abriga toda a parte acadêmica, que se resume, essencialmente, nos cursos de graduação e pós-graduação.

No âmbito do trabalho desenvolvido pela FUB, depara-se com diversos processos os quais norteiam suas atividades nas diversas áreas do conhecimento humano. Estes processos podem ser entendidos como processos administrativos e processos de ensino, de pesquisa, de extensão etc. que nos dão uma perspectiva da ação da FUB e da sua utilidade como meio de desenvolvimento da sociedade.

Em referência aos processos administrativos, a Lei 8.666 de 21 de junho de 1993, orienta as administrações públicas quanto aos procedimentos relativos às formalizações de contratos, em que o órgão público se coloca em um dos pólos, como contratante ou contratada e a outra parte, órgão público ou privado, em outro pólo, numa das mesmas situações.

Esta lei existe no intuito de se estabelecer normas gerais sobre licitações e contratos administrativos pertinentes a obras, serviços (inclusive de publicidade), compra, alienações e locações no âmbito dos Poderes da União, dos Estados, do Distrito Federal e dos Municípios (Lei 8.666/93).

Para regular as parcerias realizadas por meio de convênios, foi criada a Instrução Normativa do Tesouro Nacional n. 001 de 15 de janeiro de 1997, a qual traz em seu preâmbulo a seguinte nota: "Disciplina a celebração de convênios de natureza financeira que tenham por objeto a execução de projetos ou realização de eventos e dá outras providências" (IN/STN, 1997, p. 01).

No âmbito da Universidade de Brasília, foi criada mediante o Ato da Reitoria $\mathrm{n}$. $1115 / 99$ a seguinte norma relativa à celebração de convênios, contratos e demais parcerias: 
O PRESIDENTE DA FUNDAÇÃO E REITOR DA UNIVERSIDADE DE BRASÍLIA, no uso de suas atribuições estatutárias, considerando a necessidade de simplificar os trâmites de apresentação, análise, aprovação e publicação de convênios, contratos e outros atos bilaterais de que seja parte a Fundação Universidade de Brasília, sem prejuízo do cumprimento estrito dos ditames legais e normativos a que esses atos estiverem sujeitos.

RESOLVE:

Art. 10 Ficam sujeitos ao exame das seguintes instâncias as propostas de convênio, de contrato...

I - instancias deliberativas:...

II - instancias técnicas:

a) O Serviço de Convênios e Contratos (SCO/DAF) - quando se tratar de atos celebrados com pessoas jurídicas nacionais - para verificação do cumprimento das formalidades legais e normativas... (ATO DA REITORIA n. 1115,1999 , p. 1).

Por determinação do Ato acima referenciado, o Serviço de Convênios e Contratos da FUB é instância obrigatória de passagem de todos os processos das unidades desta Fundação, relativos à celebração de instrumentos jurídicos, em âmbito nacional.

Dentre outras normas existentes na FUB, uma em especial estabelece diretrizes para captação de recursos financeiros por meio de convênios e contratos:

O REITOR DA UNIVERSIDADE DE BRASÍLIA E PRESIDENTE DO CONSELHO DE ADMINISTRAÇÃO, no uso de suas atribuições, de acordo com a decisão em 249a Reunião Ordinária, realizada em 23/07/98, considerando a Decisão n. 473/96 do Tribunal de Contas da União.

RESOLVE:

Artigo 1ำ - As Unidades Acadêmicas, Administrativas e Complementares da UnB, devem considerar, como parte de suas atividades, o esforço permanente na captação de recursos...

Artigo $4^{\circ}$ - As atividades de captação de recursos, os instrumentos legais e suas alterações devem ser encaminhados, via titular da Unidade a que se vincula o projeto, a Procuradoria Jurídica da FUB, via Serviço de Convênios e Contratos, para cumprimento do disposto no Artigo $3^{\circ}$, $\S 3^{\circ}$, desta Resolução (RESOLUÇÃO DO CONSELHO DE ADMINISTRAÇÃO N. 001, 1998, P. 1).

O Estatuto da UnB determina como competência da Subsecretaria de Comunicação Administrativa - SCA da UnB, planejar, coordenar, executar e controlar as atividades relativas ao recebimento, expedição, protocolização e distribuição de documentos, expedientes e correspondências do interesse da FUB, bem como as publicações dos atos oficiais da Instituição. No âmbito de suas atividades, processo é o conjunto de documentos reunidos em capa própria e acumulados de forma organizada no decurso de uma ação administrativa ou judiciária. Forma-se um processo quando o 
documento exige um estudo mais detalhado, com pareceres técnicos, despachos, anexos, ou mesmo para pagamento de despesas da FUB (SCA, 2006).

\title{
2.2 Análises e comparações com estudos já existentes
}

O pouco conhecimento ou até mesmo o desconhecimento destas leis e normas por parte da comunidade universitária impede, muitas das vezes, a eficiente formalização e tramitação dos processos administrativos internos da UnB.

Almeida (2002), fala da abrangência dos processos que podem envolver tanto diferentes setores, como um determinado indivíduo:

\begin{abstract}
Processos podem abranger diferentes departamentos, diretorias, localidades, companhias e até mesmo países. Porém, podem também ter uma abrangência tão restrita quanto as atividades executadas por um único funcionário!

Para "acontecer" uma carimbada num documento, há necessidade de que o carimbador tenha recebido várias entradas, ou inputs, tais como carimbos, almofada, tinta e documentos a serem carimbados, bem como indicações que Ihe possibilitem saber que carimbo utilizar, em diferentes circunstâncias. (ALMEIDA, 2002, p. 36).
\end{abstract}

Nesta linha de raciocínio, Almeida leva a dedução de que, para que um processo tenha início, meio e fim, faz-se necessário seguir certas normas e procedimentos imprescindíveis ou inevitáveis, sem os quais torna-se inviável a conclusão do mesmo.

Assunção e Mendes (2000), citam como a maneira de organizar e gerir uma empresa pode influenciar na sua eficiência e eficácia:

A maneira de organizar e gerir as organizações têm influência direta no impacto de suas operações, estas devem desenvolver um comportamento gerencial mais integrado e abrangente, que busque a efetividade de seus processos essenciais. Por isso os administradores devem se preocupar continuamente com a reavaliação de suas práticas administrativas, a fim de garantir sustentabilidade organizacional (ASSUNÇÃO; MENDES, 2000, p. 01).

Adaptando-se esta idéia para a realidade da UnB, estes mecanismos de gerenciamento de processos podem estar relacionados àqueles vividos no âmbito de cada unidade acadêmica e/ou administrativa.

Os diversos processos que passam no dia-a-dia dos professores, alunos e funcionários técnico-administrativos dão nitidamente a idéia dos resultados que se pode alcançar com a atuação de cada um. 
Segundo Pedro (2004), um conjunto de atividades estruturadas, desenhadas para produzir um determinado output são elementos importantes na configuração de um processo:

\begin{abstract}
Um processo é um conjunto de atividades estruturadas, desenhadas para produzir um determinado output para um cliente ou mercado. Os gestores da organização onde este processo se inclui devem avaliar o próprio processo em todas as suas dimensões, recursos ação e resultados, estabelecendo ainda a integração da organização com outros macroprocessos do meio onde se insere. (...) Um processo é assim uma organização específica de atividades através do tempo e do espaço, com um início, um fim, com inputs e outputs claramente identificados: é uma estrutura para a ação integrada (PEDRO, 2004, p. 20).
\end{abstract}

Neste contexto, constata-se na FUB vários exemplos de docentes que realizam pesquisas importantes e que os frutos destas pesquisas podem ser levados ao consumo da sociedade, atendendo a um dos objetivos da existência da universidade pública. O produto da pesquisa, independentemente da área de atuação, beneficia não somente a própria universidade, mas também a cidade onde ela se encontra, o país ou até mesmo o mundo.

Desta forma, um professor autor de um projeto ou de uma tese inédita, pode despertar, e desperta o interesse de outros setores da sociedade, que vê naquele projeto algo interessante para si ou, em se tratando de Governo Federal, algo que possa beneficiar uma determinada população, ou complementar uma determinada pesquisa ou projeto.

O professor ao perceber ou receber uma manifestação positiva em relação ao seu trabalho, vai a campo para a tratativa das formas pelas quais se dará a utilização de seu produto.

De acordo com Stoner e Freeman (1999, p. 5-11), "Os dirigentes passam boa parte de seu tempo negociando porque apenas eles têm o conhecimento e a autoridade exigidos por este papel”.

Leia-se no presente contexto que o professor é o negociador e a negociação é de suma importância para o sucesso do todo. Ou seja, o detentor do projeto deverá verificar, no momento da negociação, do planejamento, quais serão as vantagens para a Administração, se os pontos negociados guardam coerência com as finalidades e objetivos da instituição; neste momento ele está investido desta autoridade de 
representar a Universidade, desde que esta representatividade esteja em sintonia com o seu sentimento de agente público.

Stoner e Freeman (1999), definem desta forma o que é planejar:

Planejar significa que os administradores pensam antecipadamente em seus objetivos e ações e que seus atos são baseados em algum método, plano ou lógica, e não em palpites (STONER; FREEMAN, 1999, p. 5-11).

Afirmam ainda que:

A administração é o processo de planejar, organizar, liderar e controlar os esforços realizados pelos membros da organização e o uso de todos os outros recursos organizacionais para alcançar os objetivos estabelecidos (STONER; FREEMAN, 1999, p. 5-11).

Neste ponto, pelo fato do professor estar vinculado ao quadro de docentes da FUB e ter desenvolvido invariavelmente grande parte de suas pesquisas no seu horário de trabalho e, após já ter negociado e traçado o mútuo plano de ação com empresas privadas ou órgãos públicos quanto à utilização do seu produto, necessita acionar a máquina da universidade para levar em frente a disponibilização do produto da sua criação.

Se a forma desta disponibilização for por meio de convênio ou de contrato, deverá o professor seguir todos os trâmites previstos no Ato da Reitoria n. 1115/99, quais sejam entre outros, o de submeter seu projeto ao crivo do Colegiado do Departamento ou do Conselho do Instituto ou da Faculdade, os quais caso aprovem o pleito, resultará obrigatoriamente na formalização de um processo de encaminhamento, seguindo o fluxo mostrado na Figura 1, obedecendo-se, de forma simples, três momentos:

1. Proposição do instrumento jurídico;

(que ocorre no âmbito de sua unidade)

2. Análise e formalização:

Serviço de Convênios e Contratos/SCO, Procuradoria Jurídica/PJU, Decanato de Pesquisa e Pós-Graduação/DPP, Decanato de Extensão/DEX, Diretoria de Acompanhamento e Integração Acadêmica/DAIA, Decanato de Ensino e Graduação/DEG etc.

3. Aprovação e assinatura:

Magnífico Reitor/MRT. 
1) Proposição do instrumento jurídico:

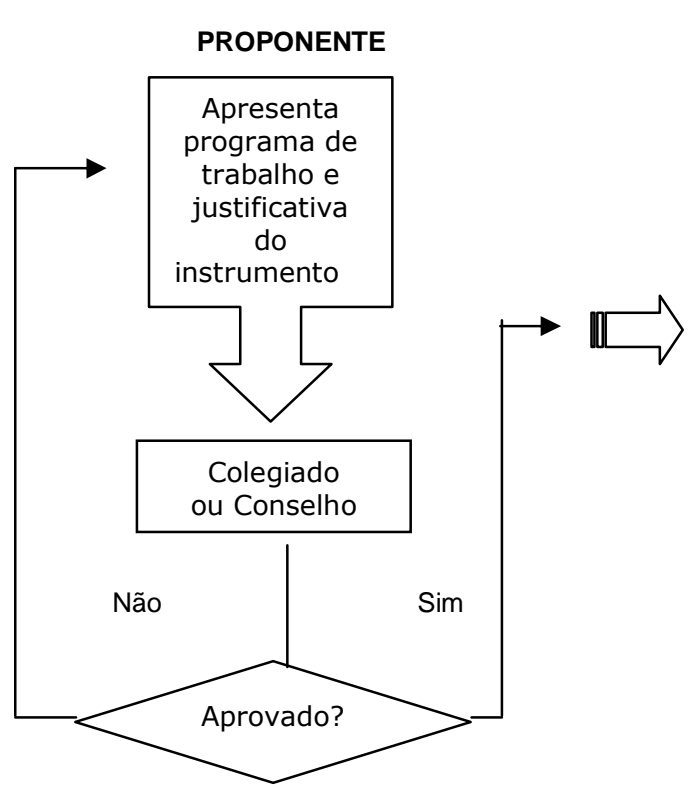

2) Análise e formalização:

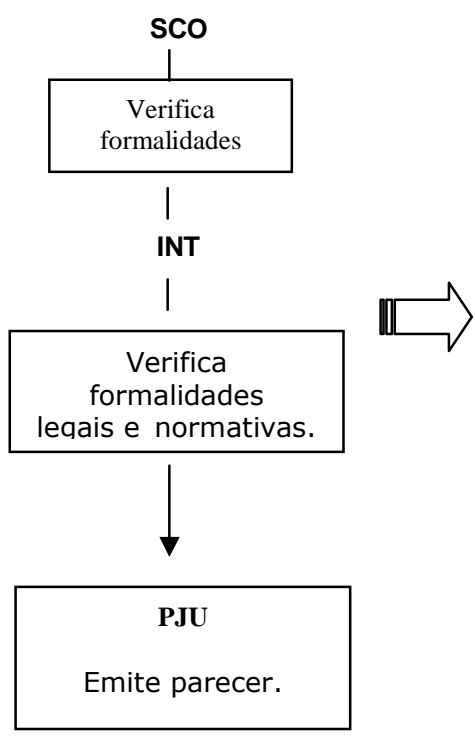

3) Aprovação e Assinatura:

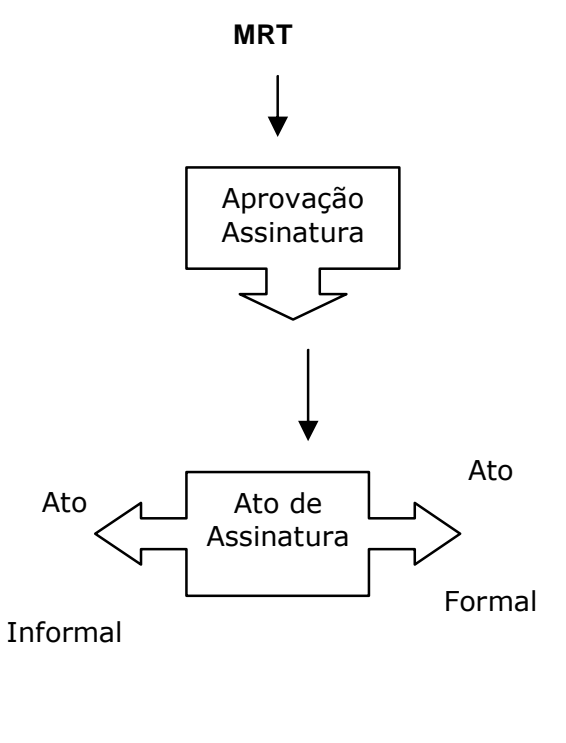

Figura 1: Fluxograma, anexo ao Ato da Reitoria n. 1115/99

Via de regra, o que geralmente acontece é o atropelo destes procedimentos de praxe e o autor do projeto, na ânsia da liberação dos recursos financeiros por parte do Contratante ou Concedente, respectivamente no caso de Contrato ou Convênio, não segue os trâmites mínimos necessários, uma vez que a FUB por se tratar de uma fundação pública não goza das liberdades inerentes a uma empresa privada.

Este fato ocasiona atrasos e impedimentos variados, idas e vindas de documentos, configurando-se numa série de transtornos que poderiam ser evitados. Confirma-se assim uma ausência de melhor organização da unidade interessada, pela ausência de um razoável entendimento sobre a parte operacional em relação ao trâmite de processos.

Segundo Stoner e Freeman (1999), o alcance dos objetivos de uma organização depende também da função organizar:

Organizar é o processo de arrumar e alocar o trabalho, a autoridade e os recursos entre os membros de uma organização, de modo que eles possam alcançar eficientemente os objetivos da mesma (STONER; FREEMAN, 1999, p. 5-11). 
$\mathrm{Na}$ esteira desta tentativa de sanar ou de amenizar os problemas gerados com a urgência na confecção dos processos, recorre-se de forma um tanto quanto precipitada às Fundações de Apoio, entidades de direito privado, sem fins lucrativos, que apóiam e incentivam atividades de ensino, pesquisa e extensão da Universidade de Brasília $(\mathrm{UnB})$, por meio do desenvolvimento e do gerenciamento de ações e de projetos institucionais.

Nestes processos iniciados na unidade acadêmica, os organizadores não se preocupam, ou se esquecem que a FUB não é uma empresa privada, e por conta disto está, como já foi dito, sob a égide de leis e normas que de certa forma "engessam" suas ações quanto se trata da celebração de convênios ou contratos.

São várias as oportunidades em que os processos mal elaborados, mal formulados são encaminhados ao Serviço de Convênios e Contratos (SCO) e/ou à Procuradoria Jurídica (PJU) da FUB para análise e parecer.

Foram colhidos junto ao SCO recentemente alguns exemplos concretos de processos elaborados incorretamente, retratando bem o nível de conhecimento de considerável parcela da FUB a respeito destes procedimentos, conforme Tabela 1 abaixo: 


\begin{tabular}{|c|c|c|c|}
\hline INSTRUMENTO & OBJETO & INTERESSADO & IRREGULARIDADES \\
\hline \multirow[t]{6}{*}{ CONVÊNIO } & \multirow[t]{3}{*}{ Estágio Curricular } & \multirow[t]{3}{*}{ Faculdade de Medicina } & $\begin{array}{l}\text { 1. Ausência de aprovação do } \\
\text { Cons/Col da faculdade; }\end{array}$ \\
\hline & & & 2. Falta de Plano de Trabalho; \\
\hline & & & $\begin{array}{l}\text { 3. Ausência dos documentos de } \\
\text { Regularidade Fiscal etc. }\end{array}$ \\
\hline & \multirow[t]{3}{*}{$\begin{array}{l}\text { Realização de } \\
\text { curso tipo Minter, } \\
\text { junto à FAP/TO. }\end{array}$} & \multirow[t]{3}{*}{$\begin{array}{l}\text { Fac. Arquitetura e } \\
\text { Urbanismo }\end{array}$} & $\begin{array}{l}\text { 1. Ausência de aprovação pelo } \\
\text { Col/Coselho da FAU e da } \\
\text { Câmara de PPG; }\end{array}$ \\
\hline & & & $\begin{array}{l}\text { 2. Ausência de Plano de } \\
\text { Trabalho; }\end{array}$ \\
\hline & & & 3. Ausência da contrapartida. \\
\hline \multirow[t]{4}{*}{ CONTRATO } & \multirow{3}{*}{$\begin{array}{l}\text { Curso de } \\
\text { Extensão para a } \\
\text { SRF. }\end{array}$} & \multirow[t]{3}{*}{ CEAD } & $\begin{array}{l}\text { 1. Ausência de manifestação da } \\
\text { outra parte; }\end{array}$ \\
\hline & & & 2. Ausência de Projeto Básico; \\
\hline & & & $\begin{array}{l}\text { 3. Falta de aprovação do Curso } \\
\text { pela Câmara de Extensão etc. }\end{array}$ \\
\hline & $\begin{array}{l}\text { Desenvolvimento } \\
\text { do setor de } \\
\text { ovinocapricultura } \\
\text { do DF, junto ao } \\
\text { SEBRAE }\end{array}$ & Fac. de Agronomia & $\begin{array}{l}\text { 1. Ausência de Projeto Básico; } \\
\text { 2. Ausência de documentação } \\
\text { do SEBRAE e de seus } \\
\text { representantes }\end{array}$ \\
\hline
\end{tabular}

Tabela 1 - Fonte: Elaboração própria a partir de dados do SCO

Não obstante o fato de se proceder com estes encaminhamentos incorretos, o maior interessado na avença, o professor e/ou a unidade acadêmica/administrativa, vai a paralelo iniciando as atividades objeto do trabalho a ser realizado, sem a finalização de todo o processo. Isto é, sem a devida assinatura por parte do representante maior da FUB, o Magnífico Reitor e a outra parte ou partícipe no respectivo instrumento jurídico.

São questões importantes que não são levadas em consideração e que podem resultar até em processo administrativo. De acordo com o Art. 8 da IN/STN n. 001/97:

Art. 8 É vedada a inclusão, tolerância ou admissão, nos convênios, sob pena de nulidade do ato e responsabilidade do agente, de cláusulas ou condições que prevejam ou permitam:

I - realização de despesas a título de taxa de administração, de gerência ou similar; 
II - pagamento, a qualquer título, a servidor ou empregado público, integrante de quadro de pessoal de órgão ou entidade pública da administração direta ou indireta, por serviços de consultoria ou assistência técnica (IN/STN n. 001, 1997, p. 6).

Tais fatos podem inviabilizar uma pesquisa e colocar a perder todo o estudo realizado, o tempo gasto, e como se não bastasse, o dinheiro do próprio bolso.

O professor ao confiar que o processo iria dar certo, investe pessoalmente no projeto na certeza de ser reembolsado posteriormente. Sem falar nos casos em que outros professores de outras localidades são envolvidos no trabalho e convidados a participar como conferencistas, palestrantes, gerando gastos com pró-labores, estadias, passagens aéreas etc e, por conseguinte uma dor de cabeça sem precedentes para a diretoria de contabilidade da FUB, que não tem os instrumentos necessários para justificar uma determinada emissão de empenho, sendo desta forma pressionado para que, de alguma forma, reembolse o gasto realizado pela unidade.

O Art. 60 da Lei de Licitações 8.666/93 prevê os seguinte termos, entre outros, para a celebração de contratos com a Administração:

Art. 60. Os contratos e seus aditamentos serão lavrados nas repartições interessadas, as quais manterão arquivo cronológico dos seus autógrafos e registro sistemático do seu extrato, salvo os relativos a direitos reais sobre imóveis, que se formalizam por instrumento lavrado em cartório de notas, de tudo juntando-se cópia no processo que lhe deu origem.

Parágrafo único. É nulo e de nenhum efeito o contrato verbal com a Administração, salvo o de pequenas compras de pronto pagamento, assim entendidas aquelas de valor não superior a $5 \%$ (cinco por cento) do limite estabelecido no art. 23, inciso II, alínea "a" desta Lei, feitas em regime de adiantamento. (Lei 8.666, 1993, p.33).

Desta forma, vê-se que a rigor nenhum procedimento relativo ao início das atividades pode ser levado a termo sem que se atente, de forma minuciosa, para o que dita a lei.

Se estes procedimentos de praxe e premissas não forem seguidas por toda a comunidade universitária, no intuito de gerir positivamente suas oportunidades de enriquecimento e valorização do saber na universidade, estes impasses e contratempos continuarão acontecendo, pois não há outro caminho a se tomar no tocante a realização de parcerias sem que as normas vigentes sejam seguidas. De outra forma, acredita-se que só mudando a lei, ou no mínimo adaptando-a à realidade e às especificidades das Instituições Públicas de Ensino Superior. 


\section{3 - Metodologia}

\subsection{Tipo de pesquisa}

Foram realizadas pesquisas bibliográficas, documentais e de campo. $\mathrm{Na}$ pesquisa bibliográfica foram realizados levantamentos referentes ao assunto em material científico publicado em livros, artigos científicos, leis e meio eletrônico. $\mathrm{Na}$ pesquisa documental, foram analisados e citados os documentos existentes na FUB. Na pesquisa de campo, foram coletados dados nas áreas administrativas e acadêmicas mediante aplicação de entrevistas.

\subsection{Entrevistas}

Colaboraram com este estudo alguns gerentes da Universidade de Brasília. Estes gerentes foram entrevistados no período de fevereiro a maio de 2006 e são detentores de cargos de direção e/ou chefias de unidades acadêmicas ou administrativas da FUB, que lidam, freqüentemente, com processos relativos à celebração de convênios e contratos.

\subsection{Instrumento}

O instrumento utilizado foi constituído de roteiro de entrevistas que investigou o entendimento e a avaliação referente às competências necessárias, para o gerente ou colaborador da FUB atuar com atividades relacionadas a convênios, contratos e demais instrumentos jurídicos bilaterais.

Para o roteiro de entrevista elaborado foram considerados os seguintes aspectos:

1. Competências necessárias para a formulação de processos de contratos, convênios e demais parcerias celebradas pela FUB;

2. Competências das unidades acadêmicas e administrativas a respeito da formalização dos processos relativos a instrumentos de parceria; 
3. O Serviço de Convênios e Contratos (SCO) está bem estruturado para atender a demanda da UnB;

4. Avaliação a respeito dos processos que chegam para análise e parecer da Procuradoria Jurídica (PJU) provenientes do SCO;

5. Avaliação do funcionamento do sistema UnBDoc;

6. As normas internas (Resoluções dos Conselhos, Atos e Resoluções da Reitoria, etc) no que concerne a Convênios e Contratos estão em sintonia com os interesses da FUB;

7. Sugestão ou dúvida quanto ao processo de formalização de contratos e convênios;

8. Dados gerais dos entrevistados.

\subsection{Procedimentos}

Os dados foram coletados mediante entrevistas com os gerentes da Universidade de Brasília. Os participantes responderam individualmente e os pesquisadores esclareceram as possíveis dúvidas.

\subsubsection{Coleta de dados da entrevista}

Foi solicitada uma autorização a estes gerentes da Universidade de Brasília para realização deste estudo. A forma de registro da entrevista foi por meio de gravação. Mediante autorização, iniciou-se os procedimentos de coleta de dados.

\subsection{Análise dos dados}

Os dados foram analisados com base nas respostas dos entrevistados as quais foram os instrumentos principais da pesquisa. Assim, com a análise das respostas dos 
entrevistados e com base na literatura estudada, pretendeu-se identificar as competências necessárias para a formulação de processos de contratos e convênios.

\section{4 - Apresentação e discussão dos resultados}

\section{1 - Entrevista com os gerentes da FUB e comentários dos pesquisadores}

\section{No entendimento de Vossa Senhoria qual é a importância da celebração de convênios e/ou contratos na FUB?}

\section{Entrevistado: Prof. Dr. César Augusto Tibúrcio Silva}

Cargo: Diretor da Faculdade de Economia, Administração, Contabilidade, Ciência da Informação e Documentação - FACE/UnB

"É de fundamental importância. Cito como exemplo o Programa Multiinstitucional que é um convênio entre quatro instituições, destacando que esse programa não sairia se não fosse o Convênio."

\section{Entrevistado: Fernando Soares dos Santos}

Cargo: Diretor de Orçamento do Decanato de Administração - DOR/DAF/UnB

"A celebração de convênios e contratos é a porta para o ingresso de mais recursos para a Universidade e é a expansão da captação para a Universidade e na maior parte dos casos tem cláusula orçamentária e financeira, trata-se de instrumentos necessários considerando hoje a escassez financeira das Instituições Federais. Acredito que deve ser muito importante e é um setor de grande valia para a Administração, além desses contratos de captação de recursos e prestação de serviços da Universidade temos os convênios que devem e podem colaborar para o crescimento da graduação e pós-graduação."

\section{Entrevistado: Maria de Jesus Queiroz}

Cargo: Chefe do Serviço de Convênios e Contratos - SCO/UnB

"É importante porque a UnB é um órgão público e é a forma de aplicar o seu conhecimento."

\section{Entrevistado: Dr. José Weber Holanda Alves}

Cargo: Procurador Geral da UnB - PJU/UnB

"A UnB tem um papel muito importante na sociedade não só no Distrito Federal mas também na sociedade brasileira e desempenha papel importante na execução de políticas públicas, principalmente voltada para a Educação Superior. Então, a 
universidade presta serviços à comunidade brasileira, não só no Distrito Federal, executando essas políticas traçadas pelo Ministério da Educação, então a importância desses contratos pode ser visto em duas vertentes, os contratos principalmente para arrecadar recursos para manter esta universidade funcionando. Como é de conhecimento de todos o que a Universidade de Brasília recebe de custeio da apenas para quatro a cinco meses do ano e os outros sete a oito meses tem que ser mantida com recursos próprios. Então, a título de exemplo, os contratos executados pelo CESPE são de fundamental importância para custear a universidade como um todo, então esses contratos são muito importantes para a universidade nesta captação de recursos. O convênio é um interesse mútuo, então a UnB tem interesse em alguns convênios para reciclar os seus professores, para treinar os seus alunos, para melhorar a qualidade de ensino, da pesquisa ou da própria extensão. Então, eu diria que é de fundamental importância a execução desses contratos e convênios para a Universidade de Brasília."

\section{Entrevistado: Rosana Andréa de Castro}

Cargo: Diretora de Esporte, Arte e Cultura - DEA/DAC/UnB

"O repasse de recursos financeiros para as IFES tem sido, a cada ano, reduzido de forma drástica. Atualmente, as universidades tanto nas áreas administrativas quanto acadêmicas têm sido motivadas, diante do quadro de escassez de recursos, a buscar parcerias nas iniciativas públicas e privadas para realizar parte de seus programas e projetos. O mecanismo burocrático de celebração de contratos e convênios é imprescindível como meio legal para que recursos financeiros sejam repassados a essas instituições além de garantir parcerias, com outros propósitos que não só financeiros, que tenham como objeto a realização de atividades relevantes para o ensino, pesquisa e extensão."

\section{Comentário:}

A FUB, inserida no cenário do Distrito Federal e nacional, depende dos repasses orçamentários e financeiros anuais vindos dos órgãos federais, ementas parlamentares e/ou dos recursos provenientes de parcerias via contratos administrativos, para que possa sobreviver de forma a manter um nível de excelência no ensino, na pesquisa e na extensão. Como bem citou o Prof. César Augusto Tibúrcio Silva, o quanto foi importante à celebração de um convênio no âmbito da FACE para a projeção da instituição.

Sabe-se, segundo informações dadas pela Diretoria de Contabilidade e Finanças (DCF) da UnB e confirmando o que disse o Dr. José Weber Holanda Alves, que os repasses orçamentários e financeiros feitos pelo Governo Federal sustentam a FUB durante quatro ou cinco meses por ano, sendo que para continuar suas atividades 
básicas, os órgãos descentralizados internos tais como, o Centro de Seleção e de Promoção de Eventos (CESPE), a Editora da Universidade de Brasília (EDU) têm papel primordial na captação de recursos via contratos, que possibilitam à FUB avançar com dignidade através dos tempos.

Além da importância financeira para a sobrevivência da FUB, os contratos e convênios têm papel significativo na interação da Universidade com a sociedade que a cerca. Os instrumentos jurídicos celebrados propiciam a interação de professores, alunos e funcionários com a comunidade local, nacional e internacional e possibilitam à sociedade buscar na Universidade solução para boa parte de seus problemas.

\section{Vossa Senhoria acha que o Serviço de Convênios e Contratos (SCO) está bem estruturado para atender a demanda da UnB e lidar com estes instrumentos?}

\section{Prof. Dr. César Augusto Tibúrcio Silva:}

"Pela experiência do Mestrado diria que sim, mas ultimamente e/ou recentemente tive uma experiência onde busquei o SCO e não tive a demanda atendida. Pretendo retornar ao SCO para obter informações pendentes."

\section{Sr. Fernando Soares dos Santos:}

"O SCO tem algumas limitações. Limitações físicas e limitações de pessoal, conforme disse anteriormente é um serviço de grande importância para a Universidade pelo o que ele pode proporcionar a UnB. O SCO não está bem estruturado hoje e há de se fazer algumas alterações, ampliação de espaço físico, qualificação de pessoal e contratação de pessoal especializado nesse assunto para poder, inclusive, fazer um trabalho de convencimento na comunidade de que ele está bem aparelhado para dar o suporte às unidades arrecadadoras e aos professores que vão buscar recursos e informações nas agências de fomento."

\section{Sra. Maria de Jesus Queiroz:}

"Não. Porque existe um volume muito grande de processo que tramita e o SCO é um Centro de Custo pequeno sem autonomia financeira com poucos recursos humanos e materiais." 


\section{Dr. José Weber Holanda Alves:}

"O nosso SCO creio que não está, apesar do esforço dos poucos servidores que tem no SCO. Estou aqui a pouco mais de 2 anos e seis meses e tenho visto a luta dos servidores do SCO, há falta de estrutura. Este setor tem ser olhado com melhores olhos pela Administração da Universidade, pois falta um número maior de pessoal qualificado, falta estagiário, falta apoio, falta talvez sistema de informática, falta contato com o seu público, com seus clientes que são os professores, falta talvez um seminário, pois tem muitos professores apesar de serem doutores na sua ciência ou na sua matéria, mas às vezes o direito administrativo deixar muito a desejar, pois muitos não sabem a diferença de Contrato e Convênio, o que é necessário para o convênio e o que é necessário para o contrato. Então, falta um roteiro, falta um fluxograma de trâmite de processo aqui dentro da Universidade, pois o professor não pode chegar com o processo debaixo do braço no Gabinete do Reitor pedindo para assinar um Convênio ou uma proposta de convênio ou um plano de trabalho sem passar pelo SCO, sem que o processo esteja devidamente instruído. Então o SCO infelizmente ainda deixa muito a desejar por isso, não pelos servidores, pois fazem um grande esforço para melhorar, mais ainda falta muita coisa. Acredito que essa Administração, o Prof. Edgar, Vice-Reitor, desta Universidade já detectou nesse começo de Administração e já falou pessoalmente que tem interesse em reestruturar esse Serviço."

\section{Sra. Rosana Andréa Costa de Castro:}

"Não. Porque falta pessoal qualificado, estrutura física e equipamentos. Não sendo essa uma prerrogativa deste setor. Os três itens apontados são recorrentes em todas as áreas administrativas na UnB. Assim como o SCO, as outras unidades carecem de estrutura para prestar um serviço compatível com a demanda de uma universidade do porte da UnB."

\section{Comentário:}

O Serviço de Convênios e Contratos além de proceder à análise técnica dos instrumentos jurídicos a serem celebrados com a FUB em nível nacional funciona como uma assessoria que procura orientar as unidades acadêmicas e administrativas na formalização destes instrumentos.

Porém, como a demanda pela realização de parcerias é consideravelmente grande, não existe no SCO uma estrutura física e profissional que faça frente ao volume de solicitações que ali chegam no dia-a-dia. Vê-se que a maioria dos entrevistados foi unânime nesta análise estrutural do Serviço de Convênios e Contratos. 
Diante do papel importante que exerce para a FUB, o SCO merece passar por uma reformulação tal, que the possibilite conduzir de forma mais eficiente e eficaz os processos de parcerias.

\section{O que Vossa Senhoria acha da compreensão dos gerentes de unidades acadêmicas/administrativas a respeito da formalização dos processos relativos a instrumentos de parceria?}

\section{Prof. Dr. César Augusto Tibúrcio Silva:}

"Baixa compreensão."

\section{Sr. Fernando Soares dos Santos:}

"O SCO bem aparelhado, bem estruturado e com pessoal qualificado vai suprir essa necessidade e essa carência de informações na Universidade, pois muitas vezes os gerentes das unidades acadêmicas e administrativas desconhecem a legislação, o procedimento e a rotina. Então, o SCO bem aparelhado vai suprir essa necessidade e vai poder expandir o conhecimento aos futuros gerentes e aos atuais gerentes das unidades acadêmicas e administrativas que estão numa fase preste a formalização de processos de Convênios e Contratos".

\section{Sra. Maria de Jesus Queiroz:}

"Eu acho os Gerentes das Unidades são incompreensíveis quando têm que cumprir burocracias e atender a legislação que rege a causa".

\section{Dr. José Weber Holanda Alves:}

"Ainda falta muita interação do SCO com os Departamentos e Faculdades para explicar a importância da formalização do processo, muitas vezes o professor não entende que tudo que ele discutiu verbalmente com uma outra entidade interessada em formar o Convênio tem que estar formalizado através de documentos e dentro do processo. Quando cheguei aqui há dois anos atrás a instrução processual era mais precária do que hoje. A gente já deu um grande passo, acho que melhorou bastante, mas tem muito a melhorar. As coisas não podem chegar de última hora, os setores têm que ter tempo para analisar o processo, as coisas não podem ter sido para ontem. Falta essa programação temporária do processo e a compreensão da Direção de que o processo não pode andar debaixo do braço, o processo tem que seguir os seus trâmites, existe a formalização, a formalidade e a parte formal é importante. O professor ou qualquer um que fale do processo, a coisa tem que ser bem escrita para que ele não precise ir ao anexo explicar o está no processo. E quando chegar um órgão de controle ou uma fiscalização é necessária que o processo esteja bem escrito, com a formalização, com as prestações de contas, com 
as notas de pagamento no caso de contrato com os planos de trabalho no caso de Convênio, ou seja, tudo que a parte formal necessita".

\section{Sra. Rosana Andréa Costa de Castro:}

"Nunca conversei com outros gestores sobre esse assunto em específico. Tenho uma impressão superficial de que há um desconhecimento relativamente grande da comunidade universitária no que concerne a esta questão".

\section{Comentário:}

Boa parte dos gerentes e colaboradores da UnB detêm pouco conhecimento a respeito dos procedimentos corretos, para a formulação e tramitação dos instrumentos jurídicos que submetem à análise das instâncias técnicas e jurídica da FUB.

Por ser uma fundação pública a FUB não goza das prerrogativas inerentes a uma empresa privada, e por conta disto, submete-se obrigatoriamente a um maior leque de leis e normas, externas e internas à instituição, que de certa forma "engessam" sua atuação na celebração, em especial, de contratos administrativos. Estes contratos são, geralmente, os carros-chefes das unidades acadêmicas para a captação de recursos.

Por este motivo, e para a redução das incorreções na formalização dos processos, os gerentes das unidades são peças fundamentais como facilitadores na solução de problemas, conduzindo seus colaboradores à correta orientação e treinamento adequado. O Dr. José Weber Holanda Alves coloca, com propriedade, o quanto é importante uma interação maior do SCO com as unidades acadêmicas e administrativas da FUB.

\section{O que Vossa Senhoria acha do trabalho realizado pela Procuradoria Jurídica - PJU, nas análises e pareceres destes instrumentos?}

\section{Prof. Dr. César Augusto Tibúrcio Silva:}

"Parece que é bom trabalho. Baseado em minha experiência que é pequena, mas por exemplo o Convênio do Programa Multiinstitucional primeiro passou pela UnB e quando passou nas outras Instituições foi rápido, então imagino que os principais problemas são solucionados." 


\section{Sr. Fernando Soares dos Santos:}

"Cabe a PJU o parecer jurídico e ao SCO o parecer técnico. A PJU se programando para atender os processos oriundos do SCO e não havendo retardamento nestas análises. O trabalho efetuado pela PJU seria o assessoramento ao Reitor e ao SCO sobre $\mathrm{o}$ aspecto jurídico dos contratos e convênios a serem formalizados pela Administração. Normalmente tem o conhecimento de que é um trabalho que está a contento realizado pela PJU. Só faço uma ressalva de que esses pareceres realizados pela PJU não sejam lentos."

\section{Sra. Maria de Jesus Queiroz:}

"A PJU é o único órgão que tem competência para dar parecer jurídico e sugerir caminhos sem ferir a lei".

Dr. José Weber Holanda Alves: Não respondeu.

\section{Sra. Rosana Andréa Costa de Castro:}

"Não tenho conhecimento de deslizes ou críticas sobre os pareceres da PJU. Ressalto que quando procurei o setor para esclarecimentos sobre os instrumentos em questão, sempre fui muito bem orientada."

\section{Comentário:}

Embora vinculada à Procuradoria Geral Federal, órgão da Advocacia Geral da União, a PJU cumpre a função de assessorar a Reitoria e as unidades e órgãos da FUB, para que a Administração obedeça à lei e proteja os interesses da Universidade, que são também interesses da União.

Talvez por desconhecer esta peculiaridade inerente à função da PJU, e em face da má formulação dos instrumentos jurídicos de parceria, considerável parcela de gerentes e colaboradores da FUB vê a Procuradoria Jurídica como um obstáculo na aprovação rápida dos seus processos que a ela são submetidos.

\section{Em relação ao sistema UnBDoc, Vossa Senhoria acha que funciona bem? Pode ser melhorado? Em que aspecto(s)?}

\section{Prof. Dr. César Augusto Tibúrcio Silva:}

"Parece que funciona bem, mas pode ser melhorado nas descrições dos documentos, pois às vezes faltam detalhes devido à descrição ser suscita. Mas o sistema funciona bem." 


\section{Sr. Fernando Soares dos Santos:}

"O sistema UnBDoc veio resgatar uma rotina de encaminhamento de processo e a minha avaliação é positiva."

\section{Sra. Maria de Jesus Queiroz:}

"Os usuários do UnBDoc estão desatualizados e esse sistema poderá ser bem melhor aproveitado."

\section{Dr. José Weber Holanda Alves:}

"Não tenho muita intimidade com o UnBDoc, mas sempre que precisei tenho localizado os processos. Além do UnBDoc as pessoas tem que ter consciência de ter o número daquele processo do serviço público federal o 23106 que é o protocolo, porque dentro da Universidade talvez o UnBDoc funciona, mas se o processo necessitar sair da esfera da FUB para o MEC ou Advocacia Geral da União necessita desse número do protocolo que é o 23106 que é o número da Universidade."

\section{Sra. Rosana Andréa Costa de Castro:}

"A iniciativa é importante, principalmente, para o acompanhamento dos processos. Sim, qualquer método ou processo deve ser passível de aperfeiçoamentos. Sugiro que o sistema impeça que o mesmo documento seja registrado mais de uma vez. É comum que, por desatenção, o mesmo número de memorando, ofício, etc. seja registrado com vários números de UnBDoc."

\section{Comentário:}

O sistema UnBDoc trouxe maior agilidade na tramitação dos processos, porém pode ser melhorado no sentido de que se façam treinamentos freqüentes com os colaboradores que atuam diretamente com o mesmo, em especial no que concerne ao aperfeiçoamento da redação, uma vez que a folha de rosto do UnBDoc traz informações resumidas sobre todo o processo. Essas precisam ser claras e diretas, para se evitar encaminhamentos equivocados, como bem coloca o Prof. César Augusto Tibúrcio Silva. 


\title{
6. Em relação às normas internas (Resoluções dos Conselhos, Atos e Resoluções da Reitoria etc) no que concerne a convênios e contratos as mesmas estão em sintonia com os interesses da FUB?
}

\author{
Prof. Dr. César Augusto Tibúrcio Silva: \\ "Parece que sim, embora quem esteja na parte operacional reclama do excesso de \\ burocracia, pois às vezes quer fazer um pagamento e tem um procedimento \\ ocasionando uma dificuldade".
}

Sr. Fernando Soares dos Santos: Não respondeu.

\section{Sra. Maria de Jesus Queiroz:}

"Não. Algumas precisam ser atualizadas".

\section{Dr. José Weber Holanda Alves:}

"Em sintonia estão. Acredito que precisa de uma maior divulgação. As pessoas não gostam de ler normas, pois gostam de ler um resumo. Talvez retirar das normas os pontos principais e o que interessa diretamente ao professor responsável pelo Contrato e Convênio. Talvez extrair algumas coisas dessas normas e ser mais objetivo para o público interessado em Contrato e Convênio. Outra coisa bastante interessante é falar do responsável pelo Convênio e Contrato. Temos que criar ato de designação. É preciso que a pessoa que seja designada tenha ciência e assine até o termo sabendo quais as suas atribuições naquele Convênio e Contrato para que ele possa ser cobrado no futuro e possa prestar contas. Acho que isso é muito importante".

\section{Sra. Rosana Andréa Costa de Castro:}

"Resoluções de Conselho, Atos e Resoluções da Reitoria são aprovadas pela comunidade universitária. Quer seja representada pela pessoa dos seus conselheiros quer seja na figura do Reitor eleito por ela. Não acredito que a comunidade universitária aprovaria posições que não estivessem em consonância com seus anseios. Talvez, o que esteja faltando, é o hábito da revisão e atualização destes documentos para que acompanhem as mudanças que, nas últimas décadas, diuturnamente têm ocorrido nesta área".

\section{Comentário:}

As normas internas são frutos de decisões tomadas em instâncias superiores da FUB, que existem para regular e facilitar os diversos procedimentos em relação à vida acadêmica e administrativa. 
A observação feita pelo Dr. José Weber Holanda Alves é importante uma vez que o número de parcerias da FUB vem aumentado consideravelmente nos últimos anos.

Faz-se necessário que os Administradores e Assessores da Universidade busquem junto ao Governo local e Federal - em especial com os legisladores - meios que facilitem e/ou diferenciais, dentro da lei, que possibilitem às Universidades Públicas mais autonomia na celebração de parcerias que visem enriquecer sua produção científica.

\section{No entendimento de Vossa Senhoria a FUB ou qualquer outra IES está} correta em tentar captar recursos via contratos de prestação de serviços?

\section{Prof. Dr. César Augusto Tibúrcio Silva:}

"O ideal seria não, se pudesse estar aqui sendo sustentado pelo governo, mas não é isso que acontece. E não tenho nenhuma expectativa, pois a captação vai continuar a acontecer como necessidade. Está super correto a captação. Gostaria de estar na Universidade só fazendo pesquisa e gostaria de não me preocupar com captação, mas imagino que isso não teria como acontecer".

\section{Sr. Fernando Soares dos Santos:}

"Além de estar correto é necessária a captação no sentido de expandir os seus recursos para a manutenção das despesas fixas e principalmente despesas com investimentos, considerando que os recursos assegurados pelo Governo Federal notadamente são insuficientes para essas despesas".

\section{Sra. Maria de Jesus Queiroz:}

"Sim".

Dr. José Weber Holanda Alves:

"Eu já falei anteriormente".

\section{Sra. Rosana Andréa Costa de Castro:}

"Como dito anteriormente, a escassez de recursos é, atualmente, o principal motivador na busca de parcerias. Não vejo problemas no objeto dos contratos e convênios, desde que, tudo seja feito dentro da legalidade e que não acarrete, em hipótese alguma, constrangimento para a imagem da nossa instituição". 


\section{Comentário:}

Em face da situação por que passa a parte financeira da FUB e das IES públicas em geral, não se vislumbra no momento outra saída para o sustento das mesmas que não seja por meio de captação de recursos. Esses advindos do Governo Federal são escassos, como já foi dito. Há de se concordar com o comentário feito pelo Prof. César Augusto Tibúrcio Silva quando afirma que o ideal seria o professor se dedicar integralmente à pesquisa e ao ensino e não se preocupar em buscar recursos para a sobrevivência das universidades.

\section{Vossa Senhoria tem alguma sugestão ou dúvida quanto ao processo de} formalização de contratos e convênios?

Prof. Dr. César Augusto Tibúrcio Silva:

"Talvez um breve manual objetivo com as normas básicas e que pudesse orientar as atividades acadêmicas".

\section{Sr. Fernando Soares dos Santos:}

"Acho que toda formalização de instrumento na UnB necessariamente deve obedecer ao trâmite que é: SCO - PJU - Gabinete do Reitor, sendo que qualquer Unidade deve buscar a informação ou arquivo sobre o assunto no SCO, pois o SCO deve estar aparelhado para informar a qualquer pessoa dentro da UnB sobre a formalização de um determinado Convênio ou Contrato".

\section{Sra. Maria de Jesus Queiroz:}

"A formalização de Contratos e Convênios e similares devem receber melhor instrução na sua origem, onde surge a intenção, ou seja, o professor poderá receber as instruções no seu próprio Centro de Custo".

Dr. José Weber Holanda Alves:

"Realizar encontros e seminários".

\section{Sra. Rosana Andréa Costa de Castro:}

"Os dados constantes no site são insuficientes. A cada processo é solicitado um documento que não constava em outros. Seria interessante a elaboração de uma cartilha sobre o assunto". 


\section{Comentário:}

Para considerável parcela de gerentes e colaboradores da FUB, há dificuldades quanto a quais documentos devem ser suficientes para atender às exigências legais para compor um processo, seja ele de contrato ou de convênio.

A lei permite que a Administração Pública realize seus contratos e convênios de forma que este procedimento the traga os melhores benefícios possíveis.

Como já foi dito anteriormente, havendo problemas quanto à atuação das Universidades Públicas em relação à sua autonomia no gerenciamento de contratos e convênios, assessores e administradores são peças fundamentais na condução de um processo de mudança de paradigmas que leve a uma alteração eficaz do atual quadro de desconhecimento pelo qual passa a universidade em relação, tanto às leis e normas internas como externas.

\section{Na avaliação de Vossa Senhoria há uma falha grave em determinado setor ou em determinada fase de tramitação do processo?}

\section{Prof. Dr. César Augusto Tibúrcio Silva:}

"Não. Fica difícil responder. Não vejo nenhum problema".

Sr. Fernando Soares dos Santos: Não respondeu.

Sra. Maria de Jesus Queiroz: Não respondeu.

Dr. José Weber Holanda Alves:

"Acho que falta conhecimento, talvez fazer um evento e trazer esses professores envolvidos nessa parte de contratos e convênios, fazer um seminário com representantes do Centro de Custo, CESPE, Editora, CDT e CET. É necessário dizer que para fazer convênio a norma diz isso, mas pontualmente precisa disso, para que esses processos não fiquem no vai e vem, quando o processo chega na PJU está faltando o Contrato Social da Empresa, quando retorna com o contrato social da empresa vem faltando o documento do responsável, sócio da empresa. Acho que é importante conscientizar os dirigentes desses Centros de Custo da importância da formalização do processo."

\section{Sra. Rosana Andréa Costa de Castro:}

"A falta de clareza na documentação necessária e a demora em solicitar retificações em processos". 


\section{Comentário:}

Em detrimento das poucas respostas obtidas, devido ao fato da pergunta exigir um tempo maior para a devida análise pelo entrevistado, com base nos documentos estudados pelos pesquisadores pode-se afirmar que a falha que se pode considerar mais marcante seria justamente no início da formalização do processo, ou até mesmo antes deste momento, quando o negociador trata com a outra parte os termos do instrumento a ser celebrado. Quando não observa o período necessário para execução do objeto ou início do mesmo, as fases seguintes ficam comprometidas.

São falhas que podem ser sanadas havendo disposição das unidades em capacitar gerentes e colaboradores.

As falhas relativas à formalização e tramitação de processos podem ser sanadas uma vez que já existe a forma, o que falta é juntar estas informações, como é proposto por meio da presente pesquisa.

10.Se Vossa Senhoria pudesse melhorar algo, qual seria o seu principal foco?

\section{Prof. Dr. César Augusto Tibúrcio Silva:}

"Após o Convênio, há muita dificuldade de acompanhamento, por isso que muitas Unidades usam a FINATEC, pois o acompanhamento é melhor. É muito mais tranqüilo trabalhar com a FINATEC, tem inclusive extrato de acompanhamento e posteriormente a Prestação de Contas. Fui executor de um Convênio e espero não ser mais, pois tive problemas com um carimbo padronizado pela Contabilidade. $\mathrm{O}$ TCU pegou justamente o Convênio com o carimbo que eu havia assinado. Tive que explicar, mas o relatório do TCU me absolveu porque foi uma coisa padronizada, mas é um tipo de situação que o executor não tinha que passar por causa de um carimbo padronizado atestando que tinha executado o serviço. $O$ acompanhamento e a prestação de contas é um ponto complicado".

Sr. Fernando Soares dos Santos: Não respondeu.

Sra. Maria de Jesus Queiroz: Não respondeu.

\section{Dr. José Weber Holanda Alves:}

"A grande preocupação hoje na Universidade é a relação da FUB com as Fundações de Apoio, pois é preciso profissionalizar a relação FUB com as suas Fundações de Apoio. Profissionalização é a relação de profissionais, um tratamento mais profissional com planos de trabalho, os projetos básicos têm que ser muito bem feitos para que possam ser encaminhados para qualquer uma das Fundações de Apoio sem necessidade de uma pessoa ter que ir junto explicar, e a Fundação de 
Apoio poder fazer uma proposta comercial, e para que faça um contrato bem feito para que haja acompanhamento e cobranças mútuas, tem que ter essa profissionalização."

\section{Sra. Rosana Andréa Costa de Castro:}

"Ter um mecanismo que regulasse a resposta a editais, encaminhamentos de solicitação de patrocínios e apoios que levem o nome da FUB."

\section{Comentário:}

As parcerias realizadas com as Fundações de Apoio são importantes, mas não deveriam ser vistas como única alternativa da FUB para reduzir problemas administrativos nos contratos realizados.

A FUB conta com uma estrutura administrativa que pode ser melhorada com treinamento e capacitação de pessoal.

Seria uma forma de reduzir custos e aumentar o potencial de recursos humanos existentes na universidade.

\section{2 - Procedimentos para encaminhamento de processos}

Com base na análise dos dados coletados e mediante as entrevistas realizadas, os autores do presente estudo propõem, a seguir, a adoção pela comunidade universitária, em especial as áreas acadêmicas e administrativas, das seguintes alternativas de encaminhamento de processos relativos à celebração de contratos, convênios e demais atos bilaterais porventura realizados pela FUB.

As dúvidas mais freqüentes surgidas no âmbito da unidade a qual pertence o gerente ou colaborador, quanto ao início de um processo de relação bilateral a qual a FUB esteja envolvida, são as seguintes:

i. Qual é a função do Serviço de Convênios e Contratos?

ii. Qual a diferença entre Contrato e Convênio?

iii. O que é Projeto Básico? Para que serve?

iv. O que é Plano de Trabalho? Para que serve?

v. Que providências tomar para iniciar um instrumento jurídico?

vi. O que é Taxa FAl? 
vii. Quais os trâmites mínimos necessários que o processo deve passar?

De acordo com o Ato da Reitoria n. 1115/99, dentre outras atribuições, cabe ao Serviço de Convênios e Contratos (SCO/DAF), verificar nos processos administrativos a ele encaminhados, o cumprimento das formalidades legais e normativas, quando se tratar de atos bilaterais celebrados pela FUB com pessoas jurídicas nacionais.

Quando os participantes têm interesses diversos e opostos, isto é, quando se deseja de um lado o objeto do acordo ou ajuste, e de outro lado, a contraprestação correspondente, ou seja, o preço, o acordo ou o ajuste, tem-se um contrato.

O Dicionário Houaiss (2001) define contrato administrativo da seguinte forma:

Contrato Administrativo é o ajuste que a administração pública firma com um particular ou outra entidade administrativa para a consecução de objetivos que traduzam o interesse público. (Dicionário HOUAISS, 2001)

Para a celebração de convênios, a Instrução Normativa da Secretaria do Tesouro Nacional n. 001/97, diz o seguinte:

Convênio é a execução descentralizada de Programa de Trabalho a cargo de órgãos e entidades da Administração Pública Federal, Direta e Indireta, que envolva a transferência de recursos financeiros oriundos de dotações consignadas nos Orçamentos Fiscais e da Seguridade Social, objetivando a realização de programas de trabalho, projeto, atividade, ou de eventos com duração certa. (IN n. 001 - STN. 1997).

Convênio, então, se caracteriza pelo instrumento que vai disciplinar esta transferência de recursos, os quais objetivam a consumação de interesses mútuos entres os partícipes, citando-se a título de exemplo a realização de obras de ampliação ou a aquisição de equipamentos para o Hospital Universitário de Brasília - HUB/FUB, a convenente, com recursos oriundos do Ministério da Saúde, a concedente.

O Projeto Básico, tanto para serviços ou obras, é peça fundamental para a celebração de um contrato, pois aquele é quem orientará a conclusão deste.

Deverá detalhar o objeto do contrato, ou seja, aquilo que se pretende realizar deverá ser detalhado, ficando clara a forma como se dará a sua operacionalização.

Neste documento não poderá ser incluída a contratação de professores, aquisição de passagens e diárias, bem como não poderá, a contratada, sub-contratar.

O Projeto Básico poderá ser apresentado pela unidade interessada, a título de exemplo, na contratação de uma Fundação de Apoio, ou qualquer outra entidade privada, cuja contratação seja por dispensa ou inexigibilidade de licitação, para que 
esta tenha subsídios no intuito de formular uma proposta de prestação de serviços para a FUB, a qual se encontra no pólo contratante.

A Unidade da FUB interessada deverá ter previsão orçamentária para cobertura das despesas referentes à execução do objeto do Contrato.

O Plano de Trabalho, de acordo com a Instrução Normativa n. 001, da Secretaria do Tesouro Nacional (1997) em seu Art. 2ํㅡㄹ é previsto da seguinte forma:

O Convênio será proposto pelo interessado ao titular do Ministério, órgão ou entidade responsável pelo programa, mediante a apresentação do Plano de Trabalho (Anexo I)...

O inciso VIII, § 1ํ, prevê o seu detalhamento:

Integrará o Plano de Trabalho a especificação completa do bem a ser produzido ou adquirido e, no caso de obras ou serviços, o projeto básico, entendido como tal o conjunto de elementos necessários e suficientes para caracterizar, com nível de precisão adequado, a obra ou serviço objeto do convênio, sua viabilidade técnica, o custo, fases ou etapas, e prazos de execução, devendo conter os elementos que dispõe o inciso IX, do art. 6ํㅡ, da Lei n. 8.666/93. (IN n. 001 - STN. 1997).

A primeira providência a ser tomada pela unidade interessada na celebração de um instrumento jurídico, é a submissão do mesmo à aprovação do Colegiado do Departamento ou, não existindo o Departamento, o Conselho do Instituto ou Faculdade, com a finalidade de decidir sobre a relevância acadêmica do programa de trabalho apresentado por docente ou pesquisador, de acordo com o que prevê o Ato da Reitoria n. $1115 / 99$.

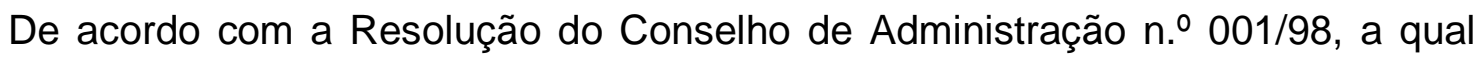
estabelece normas para captação e gestão de recursos financeiros por meio de convênios e contratos, a taxa relativa ao Fundo de Apoio Institucional/FAI, prevê que do total dos recursos captados mediante a prestação de serviços, será deduzido um percentual de, no mínimo, 10\% (dez por cento), a ser alocado ao FAl para ser incorporado ao Orçamento Programa Interno.

Posteriormente à análise dos procedimentos adotados por grande parcela da comunidade universitária relativos ao início, desenvolvimento e finalização da maioria dos processos que visam a celebração de atos bilaterais envolvendo a FUB, bem como das entrevistas desenvolvidas com seus diversos gerentes e colaboradores, detectouse a necessidade da proposição de um guia que objetive orientar de forma mais sucinta 
e direta a tramitação dos referidos processos no âmbito da Universidade de Brasília, proposta esta que segue abaixo.

Após o procedimento previsto no anexo do Ato da Reitoria n. 1115/99, descrito no item 1 da Figura 1, os pesquisadores propõem um caminho julgado o melhor para a tramitação do processo.

Antes, porém, dos procedimentos seguintes, o negociador da unidade acadêmica ou administrativa deverá estabelecer com a outra parte a qual negocia a avença, as condições em que se dará a mesma, ou seja, o preço, a forma de pagamento, o prazo para realização do objeto, o material de consumo e permanente a ser adquirido, o local de realização do objeto, o pessoal envolvido etc. De posse destas informações o negociador apresentará um programa ou proposta de trabalho para apreciação das instâncias citadas no item 1.

De forma genérica, a tramitação do processo após a aprovação da unidade responsável, deve seguir as seguintes instâncias obrigatórias da FUB para as devidas análises, pareceres e assinaturas, conforme descrito na Tabela 2 abaixo.

Ele é composto, ainda, da folha de rosto contendo o respectivo registro no sistema UnBDoc, unidade interessada, destino etc, memorando ou carta de encaminhamento assinado pelo responsável pela unidade, identificando sua intenção e inclusão dos demais documentos que serão descritos adiante.

\begin{tabular}{|c|c|c|c|c|c|c|c|c|}
\hline \multirow[b]{2}{*}{ Instrumento Jurídico } & \multicolumn{8}{|c|}{ Instâncias obrigatórias } \\
\hline & SCA & sco & PJU & DPP & DEX & DAIA & DEG & GRE \\
\hline $\begin{array}{l}\text { Contratos para realização de cursos de } \\
\text { especialização (lato sensu) - Receita }\end{array}$ & $\mathrm{x}$ & $x$ & $x$ & $x$ & & & & $x$ \\
\hline $\begin{array}{l}\text { Contratos para prestação de serviços - } \\
\text { Receita }\end{array}$ & $x$ & $x$ & $x$ & & & & & $x$ \\
\hline $\begin{array}{l}\text { Contratos para aquisição de serviços - } \\
\text { Despesa }\end{array}$ & $\mathrm{x}$ & $x$ & $x$ & & & & & $x$ \\
\hline $\begin{array}{l}\text { Contratos para realização de cursos de } \\
\text { extensão - Receita }\end{array}$ & $x$ & $x$ & $x$ & & $x$ & & & $x$ \\
\hline $\begin{array}{l}\text { Convênios com órgãos públicos } \\
\text { (descentralização de créditos) }\end{array}$ & $x$ & $x$ & $x$ & & & & & $x$ \\
\hline $\begin{array}{l}\text { Convênios de Estágio e/ou Intercâmbio de } \\
\text { estudantes }\end{array}$ & $x$ & $x$ & $x$ & & & $x$ & $x$ & $x$ \\
\hline $\begin{array}{l}\text { Protocolos de Intenções, Convênios ou } \\
\text { Acordos de Cooperação e similares }\end{array}$ & $\mathrm{x}$ & $x$ & $x$ & & & & & $x$ \\
\hline
\end{tabular}

Tabela 2 - Fonte: Elaboração própria com base em normas internas da FUB 


\section{3 - Proposta de Roteiro para Tramitação de Processos}

Os pesquisadores do presente estudo propõem um roteiro, sito aos Apêndices 2, 3 e 4, como subsídio para orientar e facilitar a formalização, encaminhamento e aprovação dos instrumentos de parceria da FUB com outros órgãos e entidades variadas.

\section{4 - Tramitação de processos relativos a Contratos de Receita:}

Documentação para processos de Contratos de Receita:

A FUB figurando no pólo de contratada.
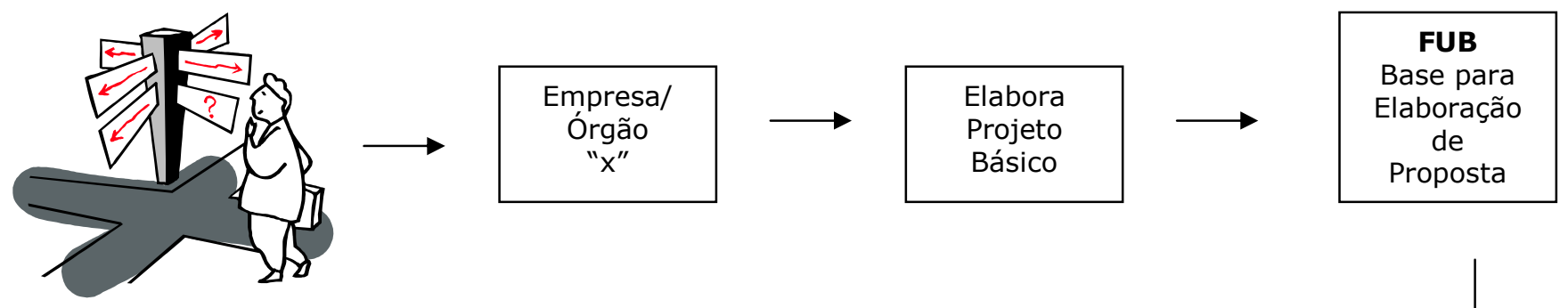

Interessado em Contratar
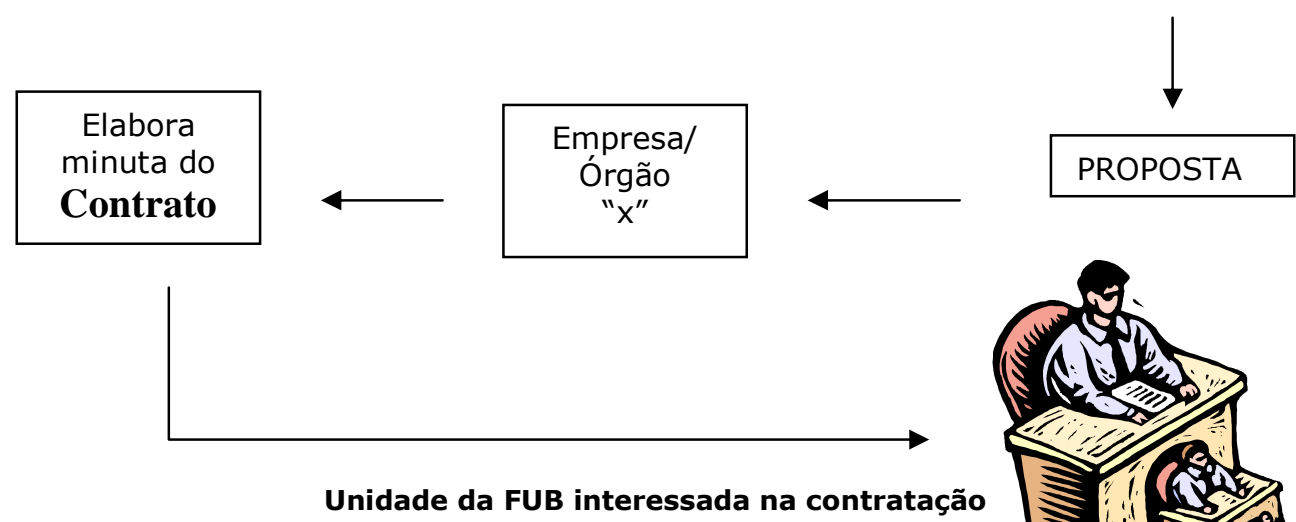

Figura 2 - Início da negociação e posterior encaminhamento

i. Para futura contratação da FUB, uma determinada empresa ou órgão apresenta um Projeto Básico;

ii. De posse do Projeto Básico, a FUB elabora uma proposta e a encaminha para a interessada;

iii. Esta, estando de acordo, elabora uma minuta do contrato. 


\subsubsection{Itens elementares que devem integrar um Projeto Básico:}

i. Título do Projeto;

ii. Objeto a ser executado;

iii. Datas de início e término (não iniciar a execução do objeto antes da assinatura do contrato - o período de execução deve coincidir com a validade do contrato);

iv. Técnicos que serão disponibilizados (coordenação e apoio - quantidade, serviços que cada um executará);

v. Disponibilização de espaço físico (quantificar e citar o horário de utilização);

vi. Disponibilização de material didático (livros, transparências, computadores, data-show etc), material de consumo (água, café, papel, giz, xerox etc) e coffee-break (quantos por dia e qual o período);

vii. Forma de pagamento.

OBS: Em casos de cursos de especialização ou de extensão, o processo deverá ser submetido à aprovação e autorização do respectivo órgão (DPP ou DEX).

\section{5 - Documentação necessária para Contratos de Despesa:}

O caminho a seguir é o mesmo, tendo como diferencial o fato da FUB figurar no pólo contratante.

$\mathrm{Na}$ elaboração do seu Projeto Básico, a FUB - por intermédio da unidade interessada - deverá citar além dos itens já enumerados no subitem 4.4.1, a fonte de recursos que cobrirá as despesas com a referida contratação.

A contratada deverá apresentar a seguinte documentação:

i. Ficha do CNPJ;

ii. Cópia da CI e CPF do representante legal da outra parte;

iii. Comprovante de competência legal para representar e assinar pela empresa; 
iv. Certidões Negativas de Débito (INSS, FGTS, DÍVIDA ATIVA E RECEITA) www.unb.br/daf/dcf/certidoes.htm;

v. Cópia do Estatuto ou Contrato Social;

vi. Credenciamento junto ao MCT e MEC (em se tratando de Fundação de Apoio).

OBS 1: Em caso de contratação sem o devido processo licitatório, a unidade deverá apresentar a justificativa da dispensa ou inexigibilidade de licitação.

OBS 2: A unidade deverá apresentar ainda a justificativa do preço pelo qual pagará pelos serviços.

\section{6 - Celebração de Convênios (descentralização de créditos):}

A FUB, por intermédio da unidade interessada, deverá propor sua participação no convênio por meio da elaboração de um Plano de Trabalho, o qual vem num modelo padronizado pela IN n. 001/97 da STN, conforme discriminado abaixo (Plano de Trabalho - fl.1/3, fl.2/3, fl.3/3), conforme Apêndice 2.

Desta forma a FUB preencherá o citado Plano de Trabalho, que é composto pelos seguintes itens:

i. Dados cadastrais do proponente (Presidente da FUB);

ii. Título do Projeto e seu período de execução (que deve coincidir com a vigência do convênio e nunca iniciar a execução do objeto antes da aprovação do instrumento);

iii. Identificação, do(s) serviço(s) a ser(em) executado(s), com respectivos órgãos internos e/ou externos envolvidos; relação com outros projetos etc;

iv. Justificativa da realização do Projeto. Sua relevância, abrangência e benefícios de seus resultados para a FUB e/ou comunidade etc;

v. Cronograma de Execução com respectivas metas, etapas ou fases;

vi. Plano de Aplicação;

vii. Cronograma de Desembolso;

viii. Assinatura do Presidente da FUB. 
Junta-se ao Plano de Trabalho a documentação da FUB - a ser providenciada pelo Serviço de Convênios e Contratos - declaração de adimplência. Após estes procedimentos, os documentos são enviados por intermédio de um Ofício da FUB ao órgão concedente dos recursos.

Caso seja aprovado, o órgão providenciará a versão final da minuta do convênio para as devidas assinaturas.

Após a assinatura do instrumento jurídico (convênio, contrato, acordo etc) pela outra parte, é imprescindível que a unidade envolvida, ao receber este documento, envie uma via original para registro no SCO e publicação no Diário Oficial da União DOU, sob pena de comprometer a eficácia do que foi acertado.

\section{7 - Outros instrumentos jurídicos}

Outras modalidades de parceria são objeto de formalização de processos nas unidades da FUB, tais como:

i. Acordos, Termos de Parceria, Protocolo de Intenções: instrumentos que, embora muito utilizados, seu objeto é muito abrangente e suas ações exigem a celebração de Convênios ou Contratos específicos; é utilizado também para possibilitar que servidores da FUB e seus dependentes, freqüentem alguns cursos de graduação em faculdades particulares, com descontos nas mensalidades.

ii. Convênios de Estágio: segundo a Portaria n. 8, do Ministério do Planejamento, Orçamento e Gestão, de 23 de janeiro de 2001, são instrumentos utilizados para proporcionar experiência prática em órgãos públicos ou privados, na linha de formação dos alunos regularmente matriculados em cursos de graduação da UnB. Além de exigir a formalização do convênio, o aluno ainda tem que preencher um Termo de Compromisso com a empresa à qual irá estagiar;

iii. Convênios de Intercâmbio: visa proporcionar a mobilidade estudantil (Andifes) dos alunos da UnB para outras IES públicas, e vice-versa. 
Geralmente confundidos com instrumentos jurídicos principais, os Termos Aditivos na verdade são utilizados como uma ferramenta secundária para promover acertos no transcorrer da vigência daqueles instrumentos principais.

Servem, no entanto para alterar o que foi pactuado no instrumento principal, bem como suprimir, incluir ou retificar suas cláusulas, no intuito de aperfeiçoá-las.

O Termo Aditivo não pode ser utilizado para mudar ou alterar o objeto do instrumento. É utilizado principalmente para prorrogar a vigência do ato bilateral celebrado entre as partes. 


\section{5 - Conclusão}

Os gerentes entrevistados reforçaram a importância do Serviço de Convênios e Contratos (SCO), pois representa o órgão da FUB que auxilia na orientação dos processos de captação de recursos para a Universidade, considerando a atual escassez financeira das instituições federais públicas de ensino superior.

Este Serviço tem como função precípua elaborar pareceres técnicos de convênios e contratos. Caso haja algum problema, é devolvido para o órgão de origem. Se o projeto estiver em conformidade, segue para Procuradoria Jurídica da Universidade (PJU). Essa emite o parecer jurídico acerca do instrumento. Desta forma, o reitor poderá assinar ou não o referido documento.

Embora pareça simples essa tramitação, há uma demora considerável para efetivação de Convênios e Contratos. O SCO apresenta déficit de pessoal qualificado, estrutura física e equipamentos. Assim, esse Serviço necessita de uma reestruturação física e profissional para prestar um serviço compatível com a demanda de uma universidade do porte da UnB, que cresce a cada dia.

No ano de 2005, a Universidade de Brasília por meio do Serviço de Convênios e Contratos captou $42,91 \%$ da movimentação orçamentária total, sendo $15,92 \%$ de convênios e $26,99 \%$ de contratos. Assim, verifica-se que a matriz orçamentária proveniente do Governo Federal não é suficiente para arcar com as despesas durante o ano inteiro. Atualmente, a Universidade tem necessidade de captar recursos externamente.

Também foi detectada a falta de padronização dos trâmites necessários para efetivação de um convênio ou contrato. Isso é decorrente da burocratização na formalização de convênios e do gasto excessivo de tempo para realizá-los. Para piorar a situação, os atuais gerentes universitários não têm dentre suas atribuições o objetivo de captar fundos para a Instituição. Mas em face da situação, se vêem na obrigação de buscar a "sobrevivência" da Universidade.

Por outro lado, poucos conhecem os trâmites necessários para formulação de tais instrumentos. 
$\mathrm{Na}$ eminente possibilidade de perderem o investimento conquistado em razão do processo lento já diagnosticado, "pulam" etapas que obrigatoriamente deveriam ser seguidas.

Desta forma, propõe-se um roteiro de condução de processos voltado para a área de convênios e contratos que propicie mais agilidade e conhecimento, focalizandose a atual situação de obtenção de recursos externamente.

Além do mais, face às dificuldades aqui já citadas e reiterando a necessidade de uma ampla reestruturação do Serviço de Convênios e Contratos, propõe-se ainda a criação de um Núcleo de Captação de Recursos que exerça influência perante as Direções das Unidades Acadêmicas e Administrativas e demais Centros da FUB, visando a adoção de procedimentos padrão para a condução de processos, objetivando sua otimização e a diminuição dos erros de tramitação.

Em paralelo a esta proposta, existe também a necessidade do treinamento de gerentes e colaboradores no intuito de que os mesmos reconheçam o grau da importância da correta formalização de processos referentes à captação de recursos para a FUB e como este procedimento pode potencializar sua atuação junto a comunidade em geral, atuando de forma a valorizar os aspectos relativos à eficiência e à eficácia.

Destarte a situação por que passa a parte financeira da FUB e das IES públicas em geral, não se vislumbra no momento outra saída para auxiliar o sustento das mesmas que não seja por meio de captação de recursos.

Faz-se necessário que os Administradores e Assessores da Universidade busquem junto ao Governo local e Federal - em especial com os legisladores - meios que facilitem e/ou diferenciais, dentro da lei, que possibilitem às Universidades Públicas mais autonomia na celebração de parcerias.

Por ser uma fundação pública a FUB não goza das prerrogativas inerentes a uma empresa privada, e por conta disto, submete-se obrigatoriamente a um maior leque de leis e normas, externas e internas à instituição, que de certa forma "engessam" sua atuação na celebração, em especial, de contratos e convênios administrativos. 
As parcerias realizadas com as Fundações de Apoio são importantes, mas não deveriam ser vistas como única alternativa da FUB para reduzir problemas administrativos nos contratos e demais operações realizadas.

A FUB possui unidades importantes as quais, havendo a devida qualificação de pessoal que ali atua, teria condições de amenizar problemas de operacionalização.

As falhas relativas à formalização e tramitação de processos podem ser sanadas mediante um roteiro simplificado. E o SCO, diante do papel importante que exerce para a FUB, merece passar por uma sensível reestruturação. 


\section{6 - Referências}

ALMEIDA, L.G. Gestão de Processos e a Gestão Estratégica. Rio de Janeiro. Qualitymark, 2002.

ASSUNÇÃO, M.A; MENDES, P.J.V. Mudança e gestão de processo em organização pública. In: $\mathrm{V}$ Congreso Internacional del CLAD sobre la Reforma del Estado y de la Administración Pública, Santo Domingo, Rep. Dominicana, 24 - 27 Oct. 2000, p. 01.

UNIVERSIDADE DE BRASÍLIA. Ato da Reitoria n. 1115, 11 de novembro de 1999. FUNDAÇÃO UNIVERSIDADE DE BRASÍLIA. Brasília, DF.

HOUAISS, Antonio; SALLES, Mauro de. Dicionário Houaiss da Língua Portuguesa, elaborado no Instituto Antonio Houaiss de Lexicografia e Banco de Dados da Língua Portuguesa S/C Ltda - Rio de Janeiro: Objetiva, 2001.

INSTRUÇÃO NORMATIVA DA SECRETARIA DO TESOURO NACIONAL n. 001 de 15 de janeiro de 1997. Diário Oficial da União, 31 de janeiro de 1997. Brasília, DF.

PRESIDÊNCIA DA REPÚBLICA. Lei de Licitações n. 8.666, 21 de junho de 1993. Brasília, DF.

PEDRO, J.M. O Balanced Scorecard (BSC) no Setor Público. http://www.instinformatica.pt/v20/documentos/p_ver/ver_28/Artigo2.pdf. P.20. 2004. Portugal.

UNIVERSIDADE DE BRASÍLIA. Resolução do Conselho de Administração n. 001, de julho de 1998. FUNDAÇÃO UNIVERSIDADE DE BRASÍLIA. Brasília, DF.

STONER, James A.F; FREEMAN, R. Edward. Administração. $5^{\underline{a}}$ ed. Rio de Janeiro: Livros Técnicos e Científicos, 1999. 


\section{7 - Apêndice 1}

Roteiro para entrevista referente ao nível de satisfação dos gerentes da FUB em relação à formalização e tramitação dos processos internos:

1. No seu entendimento qual é a importância da celebração de convênios e/ou contratos na FUB?

2. Você acha que o Serviço de Convênios e Contratos - SCO está bem estruturado para atender a demanda da UnB e lidar com estes instrumentos?

3. O que você acha da compreensão dos gerentes de unidades acadêmicas/administrativas a respeito da formalização dos processos relativos a instrumentos de parceria?

4. O que você acha do trabalho realizado pela Procuradoria Jurídica - PJU nas análises e pareceres destes instrumentos?

5. Em relação ao sistema UnBDoc, você acha que funciona bem? Pode ser melhorado? Em que aspecto(s)?

6. Em relação às normas internas (Resoluções dos Conselhos, Atos e Resoluções da Reitoria etc) no que concerne a convênios e contratos as mesmas estão em sintonia com os interesses da FUB?

7. No seu entendimento a FUB ou qualquer outra IES está correta em tentar captar recursos via contratos de prestação de serviços?

8. Você tem alguma sugestão ou dúvida quanto ao processo de formalização de contratos e convênios?

9. Na sua avaliação há uma falha grave em determinado setor ou em determinada fase de tramitação do projeto?

10. Se pudesse melhorar algo, qual seria o seu principal foco? 


\section{8 - Apêndice 2}

ANEXO I

PLANO DE TRABALHO - fl. 1/3

\section{1 - DADOS CADASTRAIS}

\begin{tabular}{|c|c|c|c|c|c|c|}
\hline \multicolumn{5}{|c|}{$\begin{array}{l}\text { Órgão/Entidade Proponente } \\
\text { FUNDAÇÃO UNIVERSIDADE DE BRASÍLIA }\end{array}$} & \multicolumn{2}{|c|}{$\begin{array}{l}\text { C.G.C } \\
00.038 .174 / 0001-43\end{array}$} \\
\hline \multicolumn{7}{|c|}{$\begin{array}{l}\text { Endereço } \\
\text { CAMPUS UNIVERSITÁRIO DARCY RIBEIRO - ASA NORTE }\end{array}$} \\
\hline $\begin{array}{l}\text { Cidade } \\
\text { Brasília }\end{array}$ & $\begin{array}{l}\text { UF } \\
\text { DF }\end{array}$ & $\begin{array}{l}\text { CEP } \\
70910-900\end{array}$ & & $\begin{array}{l}\text { DDD/Telefone } \\
061-307-2201\end{array}$ & & E.A \\
\hline $\begin{array}{l}\text { Conta Corrente } \\
170500-8\end{array}$ & \multicolumn{2}{|c|}{$\begin{array}{l}\text { Banco } \\
001\end{array}$} & $\begin{array}{l}\text { Agência } \\
3.602-1\end{array}$ & & \multicolumn{2}{|c|}{$\begin{array}{l}\text { Praça de Pagamento } \\
\text { BRASÍLIA }\end{array}$} \\
\hline \multicolumn{5}{|c|}{$\begin{array}{l}\text { Nome do Responsável } \\
\text { Nome do Reitor }\end{array}$} & \multicolumn{2}{|l|}{ CPF } \\
\hline Cl / Órgão Exp. & \multicolumn{2}{|c|}{$\begin{array}{l}\text { Cargo } \\
\text { Professor }\end{array}$} & \multicolumn{2}{|c|}{$\begin{array}{l}\text { Função } \\
\text { Reitor }\end{array}$} & & Matrícula \\
\hline \multicolumn{5}{|l|}{ Endereço } & \multicolumn{2}{|l|}{ CEP } \\
\hline
\end{tabular}

\section{2 - OUTROS PARTÍCIPES}

\begin{tabular}{|l|l|l|}
\hline Nome: & CNPJ/CPF & Esfera Administrativa \\
\hline Endereço & \\
\hline
\end{tabular}

\section{3 - DISCRIMINAÇÃO DO PROJETO}

\begin{tabular}{|c|c|c|}
\hline \multirow{2}{*}{$\begin{array}{l}\text { Título do Projeto } \\
\text { Nome do projeto }\end{array}$} & \multicolumn{2}{|c|}{$\begin{array}{c}\text { Período de Execução } \\
\text { (Deve coincidir com a vigência do } \\
\text { Convênio) } \\
\text { Obs: Jamais iniciar a execução antes da } \\
\text { aprovação do instrumento. }\end{array}$} \\
\hline & Início & Término \\
\hline \multicolumn{3}{|l|}{ Identificação } \\
\hline \multicolumn{3}{|c|}{$\begin{array}{l}\text { Identificar, resumidamente, o(s) serviço(s) a ser(em) executado(s), com respectivos órgãos internos } \\
\text { e/ou externos envolvidos; relação com outros projetos etc. }\end{array}$} \\
\hline \multicolumn{3}{|c|}{ Justificativa da Proposição } \\
\hline \multicolumn{3}{|c|}{$\begin{array}{l}\text { Justificar a realização do Projeto. Sua relevância para a FUB. Abrangência e benefícios de seus } \\
\text { resultados para a FUB e/ou comunidade etc. }\end{array}$} \\
\hline
\end{tabular}


ANEXO I

PLANO DE TRABALHO $\mathrm{fl} .2 / 3$

4 - CRONOGRAMA DE EXECUÇÃO (Meta, Etapa ou Fase)

\begin{tabular}{|c|c|c|c|c|c|c|}
\hline \multirow{2}{*}{ Meta } & \multirow{2}{*}{$\begin{array}{c}\text { Etapa/ } \\
\text { Fase }\end{array}$} & \multirow{2}{*}{ Especificaçäo } & \multicolumn{2}{|c|}{ Indicador Físico } & \multicolumn{2}{|c|}{ Duração } \\
\hline & & & Unidade & Quantidade & Início & Término \\
\hline $1,2,3$, etc. & $1,2,3$ etc. & $\begin{array}{l}\text { Especificação dos serviços a serem realizados } \\
\text { em cada meta, etapa/fase. }\end{array}$ & $\begin{array}{c}\text { Aula; } \\
\text { Exposição } \\
\text {; Visita; } \\
\text { Seminário; } \\
\text { etc. }\end{array}$ & Numerário & $\begin{array}{l}\text { De cada } \\
\text { meta, } \\
\text { etapa } \\
\text { e/ou } \\
\text { fase. }\end{array}$ & $\begin{array}{c}\text { De cada } \\
\text { meta, etapa } \\
\text { e/ou fase. }\end{array}$ \\
\hline
\end{tabular}

5 - PLANO DE APLICAÇÃO ( R\$ 1,00)

\begin{tabular}{|c|l|l|l|l|}
\hline \multicolumn{2}{|c|}{ Natureza da Despesa } & \multirow{2}{*}{ Total } & Concedente & Proponente \\
\hline Código & \multicolumn{1}{|c|}{ Especificação } & & $\begin{array}{l}\text { Valor dos } \\
\text { recursos } \\
\text { concedidos. }\end{array}$ & $\begin{array}{l}\text { Valor - se no } \\
\text { caso a FUB } \\
\text { está } \\
\text { oferecendo } \\
\text { Rubricantrapartida. }\end{array}$ \\
& $\begin{array}{l}\text { Ex: Material de Consumo; Outros Serviços de } \\
\text { Terceiros - Pessoa Jurídica ou Física; Materiais e } \\
\text { Equipamentos; Auxílio Financeiro a Estudantes } \\
\text { etc. }\end{array}$ & & & \\
\hline \multicolumn{2}{|c|}{ Total Geral } & & & \\
\hline
\end{tabular}


ANEXO I

PLANO DE TRABALHO - fl. 3/3

\section{6 - Cronograma de Desembolso ( $R \$ 1.00)$}

\section{Concedente}

\begin{tabular}{|l|l|l|l|l|l|l|}
\hline Meta & Jan & Fev & Mar & Abr & Mai & Jun \\
\hline $\begin{array}{l}\text { Recursos a } \\
\text { serem } \\
\text { desembolsados } \\
\text { no decorrer do } \\
\text { período de } \\
\text { execução do } \\
\text { Objeto, de } \\
\text { acordo com } \\
\text { cada meta. }\end{array}$ & & & & & & \\
\hline Meta & Jul & Ago & Set & Out & Nov & Dez \\
\hline
\end{tabular}

Proponente (Contrapartida)

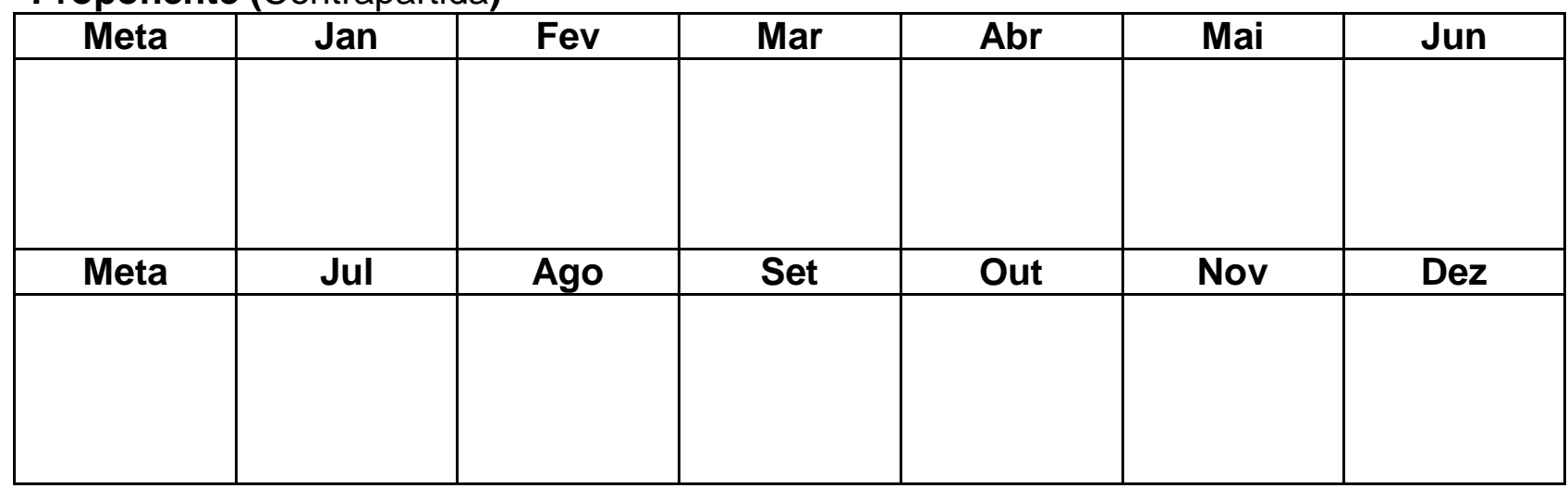

\section{7 - Declaração}

$\mathrm{Na}$ qualidade de representante legal, declaro para fins de prova junto a (entidade concedente dos recursos), para os efeitos e sob penas da lei, que inexiste qualquer débito em mora ou situação de inadimplência com o Tesouro Nacional ou qualquer órgão ou entidade da Administração Pública Federal, que impeça a transferência de recursos oriundos de dotações consignadas nos orçamentos da União, na forma deste plano de trabalho.

\section{Pede deferimento}

\section{8 - Aprovação pela Concedente}

Aprovado

Figura 3 - Instrução Normativa do Tesouro Nacional n. 001/97, comentada pelos pesquisadores. 


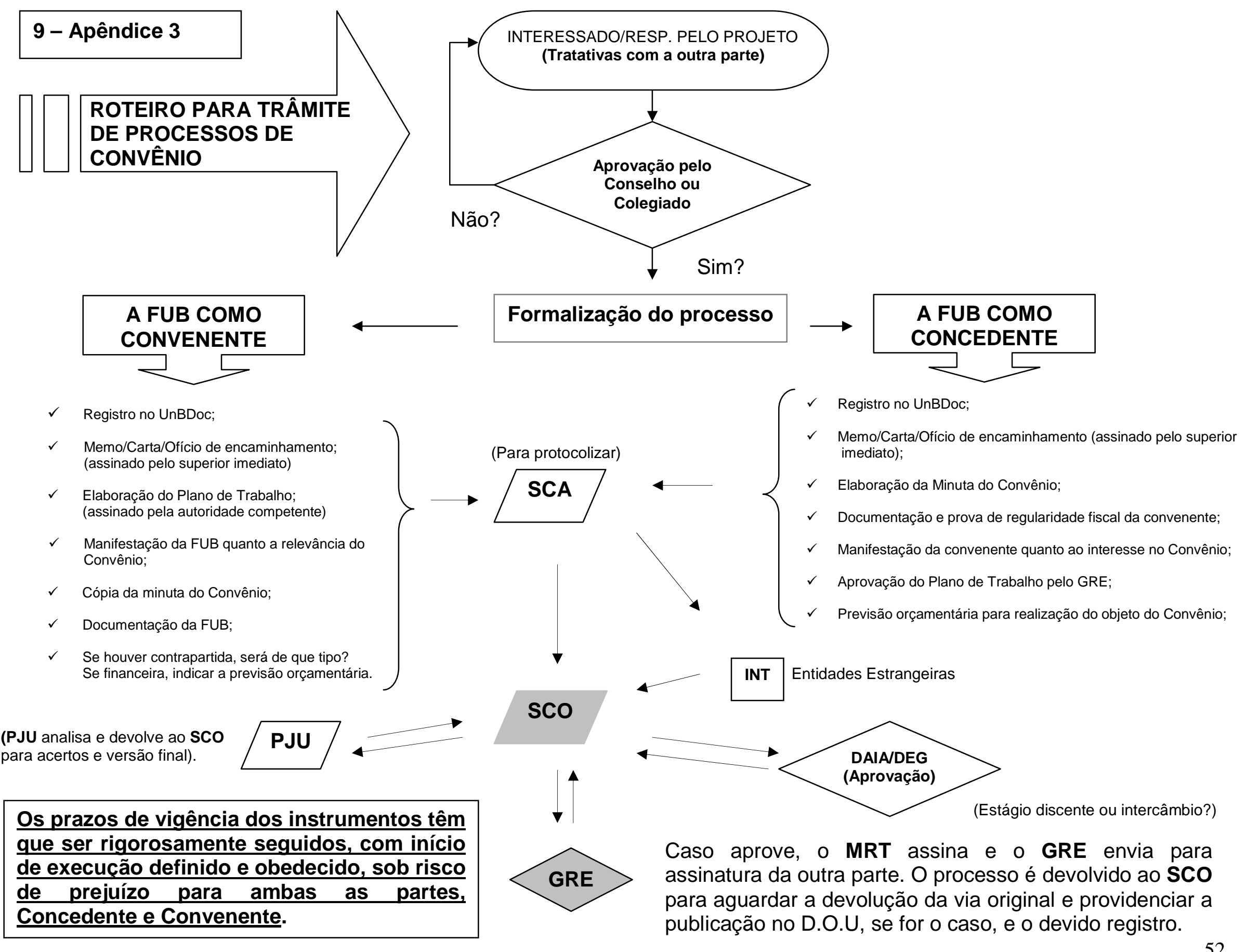




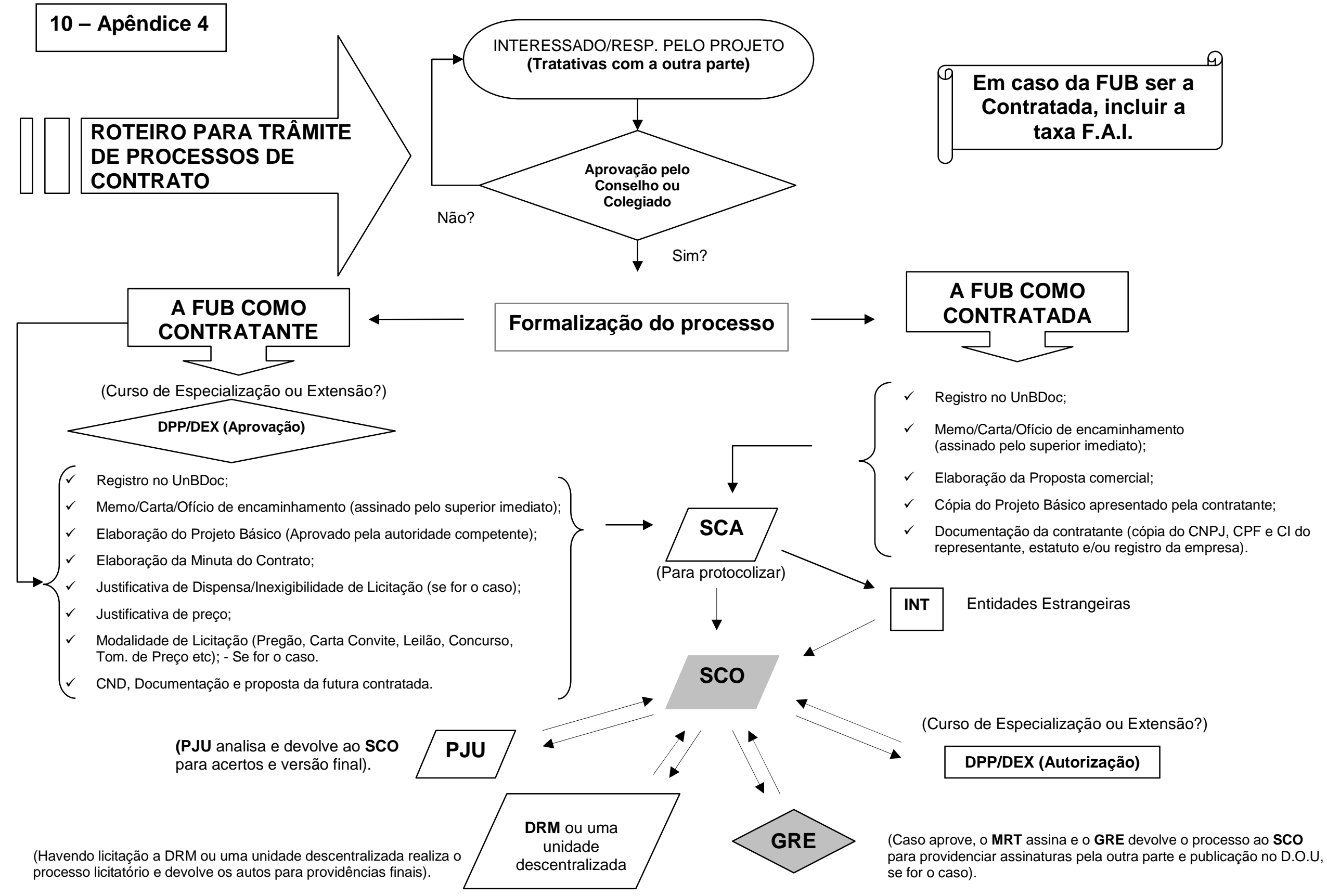


11 - LE GE N D A

FAI - Fundo de Apoio Institucional

DPP - Decanato de Pesquisa e Pós-Graduação

DEX - Decanato de Extensão

SCA - Subsecretaria de Comunicação Administrativa

INT - Assessoria de Assuntos Internacionais

SCO - Serviço de Convênios e Contratos

PJU - Procuradoria Jurídica

DRM - Diretoria de Recursos Materiais

GRE - Gabinete do Reitor

MRT - Magnífico Reitor

DAIA - Diretoria de Acompanhamento e Integração Acadêmica

DEG - Decanato de Ensino e Graduação 
12 - LISTA DE FIGURAS E TABELAS

Figura 1 - Fluxograma, anexo ao Ato da Reitoria n. 1115/99.

Figura 2 - Início da negociação e posterior encaminhamento.

Figura 3 - Instrução Normativa do Tesouro Nacional n. 001/97, comentada pelos pesquisadores.

Tabela 1 - Fonte: Elaboração própria a partir de dados do ScO.

Tabela 2 - Fonte: Elaboração própria com base em normas internas da FUB. 